NBER WORKING PAPER SERIES

\title{
HOW DO THE BETTER EDUCATED DO IT? SOCIOECONOMIC STATUS AND THE ABILITY TO COPE WITH UNDERLYING IMPAIRMENT
}

\author{
David M. Cutler \\ Mary Beth Landrum \\ Kate A. Stewart \\ Working Paper 12040 \\ http://www.nber.org/papers/w12040
NATIONAL BUREAU OF ECONOMIC RESEARCH
1050 Massachusetts Avenue
Cambridge, MA 02138
February 2006

David M. Cutler is the Otto Eckstein Professor of Applied Economics and Dean for the Social Sciences at Harvard University and a research associate of the National Bureau of Economic Research, Mary Beth Landrum is Associate Professor of Biostatistics in the Department of Health Care Policy and Kate A. Stewart is a PhD candidate in Health Policy at Harvard University. We are grateful to Michael Hurd and members of the National Bureau of Economic Research Aging Group for comments on an earlier version. This work was funded by the National Institute of Aging (R01AG019805). The views expressed herein are those of the author(s) and do not necessarily reflect the views of the National Bureau of Economic Research.

(O2006 by David M. Cutler, Mary Beth Landrum and Kate A. Stewart. All rights reserved. Short sections of text, not to exceed two paragraphs, may be quoted without explicit permission provided that full credit, including $(\odot$ notice, is given to the source. 
How Do the Better Educated Do It? Socioeconomic Status and the Ability to Cope with Underlying Impairment

David M. Cutler, Mary Beth Landrum and Kate A. Stewart

NBER Working Paper No. 12040

February 2006

JEL No. I1, J1

\section{ABSTRACT}

There is a pronounced gradient in disability across socioeconomic groups, with better educated and higher income groups reporting substantially less disability. In this paper, we consider why that is the case, focusing on impairments in basic physical and cognitive aspects of living for the elderly. Our empirical work has two parts. First, we consider how much of this gradient in disability is a result of underlying differences in functioning versus the ability to cope with impairments. We show differences in functioning are the major part of the difference in disability, but both are important. Second, we consider how the better educated elderly cope with disability. Better educated people use substantially more assistive technology than the less educated and are more likely to use paid help. But use of these services is not the primary reason that the better educated are better able to cope. We conclude with thoughts about other potential factors that may explain differential coping.

David M. Cutler Department of Economics Harvard University 1875 Cambridge Street

Cambridge, MA 02138 and NBER

dcutler@harvard.edu

Mary Beth Landrum Department of Health Care Policy Harvard Medical School 180 Longwood Avenue Boston, MA 02115 landrum@hcp.med.harvard.edu
Kate A. Stewart

Department of Health Care Policy Harvard Medical School 180 Longwood Avenue Boston, MA 02115 kstewart@hsph.harvard.edu 
The pronounced gradient in health among people in different socioeconomic groups is well known. People who are richer or better educated live longer and have higher quality of life than people in lower SES groups. The reason for this difference is not well understood, however. Health results from decisions made throughout the lifecourse (McGinness and Foege, 1993), perhaps even before birth (Barker, 1994). To date, most attempts to explain the gradient have come up shorthanded (Adler et al., 1993), even those exploring health differences among youths (Case, Lubotsky, and Paxson, 2002). In this paper, we focus on one particular dimension of the socioeconomic gradient in health. We examine how elderly people in different socioeconomic groups cope with disability in performing basic personal care activities, including dressing, bathing, and getting around inside, and activities required to live independently, such as preparing meals, grocery shopping and managing money.

Gradients in disability by socioeconomic status have been found in a large number of studies (see for example Fried and Guralnik, 1997, Stuck et al 1999, and Guralnik, Fried and Salive, 1996 and the references therein) and recent studies have documented growing disparities in disability by socioeconomic status (Crimmins and Saito, 2001; Schoeni et al, 2005). Two recent studies have attempted to understand the causal pathways between socioeconomic status and disability by examining transitions between health states using longitudinal data. Zimmer and House (2003) decompose the association between education, income and prevalent disability into two pieces: onset of new disability and progression among those disabled. They find that both income and education is associated with onset but only income predicts subsequent progression 
suggesting that income can serve both to prevent ill health and allow individuals to better manage illness. Similarly, Melzer et al (2001) examined incidence, recovery and mortality rates by educational attainment and found that education was strongly associated with incidence of disability but not related to recovery or risk of death among the disabled. In these studies, recovery or progression of disability could results from a number of factors including better management of the diseases underlying the limitations and better ability to cope with limitations. In this paper, we examine a single piece of this puzzle and consider whether differences in coping strategies allow the better off to resolve their disability more effectively than the less well off.

The motivation for our analysis is provided in Figure 1. Panel A of the figure shows the age and sex-adjusted income and education gradients in impairment in any of a number of measures of self-care tasks such as bathing, dressing, and related activities (the data set and specific measures of disability are described later). We show impairment even accounting for the use of personal and technological aids. There is a very pronounced education relation in this measure of disability. Among those with less than any high school education, about 8 percent of the elderly are disabled. In the highest education group, those who are college grads, the rate is half as high. There is a moderate income gradient in disability as well, although the difference is primarily between the very poor - those earning below $\$ 10,000$ - and everyone else.

Panel B of the figure shows the income and education gradients in impairment in various measures of independent functioning such as the ability to shop or do light housework. The story is very similar. Over 20 percent of the elderly with less than any high school are disabled, compared to below 15 percent among those with some college 
or more. There is also an income gradient in impairment along these dimensions. With one exception (people earning $\$ 40,000-\$ 49,000$ per year), disability declines monotonically with higher income.

Our analysis considers two primary issues. First, we ask how much of this gradient in health is a result of underlying differences in functioning versus the ability to cope with impairments. We show that while the bulk of the difference is a result of underlying functioning - the better off have much less difficulty with these measures even in the absence of help - coping is important as well. The better educated are less likely to have functional disabilities in the first place, and cope with them better when they occur.

Second, we consider how the better educated elderly cope, and in particular whether the use of personal help and technological aids are important for successful coping. Better educated people use substantially more assistive technology than the less educated and are more likely to use paid help. Surprisingly, they are substantially less likely to use help from relatives, so that overall use of personal care is actually lower among the better educated than among the less educated, even given their functional status.

Knowing about use of aids or paid help does not explain the education gradient in coping, however. Controlling for type of coping strategies does not affect in a material way the pronounced education gradient in coping with disability. We speculate that perhaps the intensity of use varies across education groups, that there is an interaction between the technology that is available and the environment in which the person lives, or that the more educated are more likely to cope through behavioral and/or 
environmental modifications (coping strategies not examined in this paper). Because our data go only so far, we leave open the analysis of these specific hypotheses.

Our paper is structured as follows. The first section discusses the disability measures we considered and the data used. The second section presents analyses of the link between socioeconomic status and disability. The third section examines alternative explanations for the education gradient in coping, and the last section presents our conclusions.

\section{Measures of Disability}

Disability is a complex concept related to a person's health, their environment and their role expectations. As such there is no perfect measure of disability. While most research in the non-elderly defines disability in terms of ability to work, we follow the lead of most researchers in measuring disability in the elderly as the presence of impairments in activities of daily living (ADLs), self-care tasks such as dressing and bathing, and instrumental activities of daily living (IADLs), tasks required to live independently such as preparing meals, doing housework and managing money. Our data source, Phase I of the National Health Interview Disability Supplement of 1994 and 1995 - abbreviated NHIS-D - includes information on 6 ADL measures: bathing, dressing, eating, transferring to and from bed, toileting, and getting around inside the home.

Questions are also asked about 6 IADL measures: grocery shopping, managing money, preparing meals, heavy housework, light housework and using the telephone.

For any particular measure of disability, there are three relevant concepts. The first is termed intrinsic disability, the share of people who report difficulty on an item in 
the absence of any help from other people or equipment. We measure intrinsic disability for ADL tasks using a set of three questions from the NHIS-D. First respondents are asked about receiving help from another person ${ }^{1}$ and about the use special equipment to perform the task. Respondents who do not report personal or equipment help to do the activity are asked if they have any difficulty performing the task. We consider respondents to have intrinsic ADL disability if they either receive help from another person, use equipment to perform a task, or deny either of these forms of help but report difficulty performing the task. The NHIS-D did not ask about the use of special equipment for IADL tasks. Thus we define respondents as having intrinsic IADL disability if they report receiving help with the task or report difficulty in the absence of help.

We define residual disability as the share of people who report difficulty on an item even with help from others or special equipment. In the NHIS-D, respondents who report using special equipment or receiving help to perform a task were also asked how much difficulty they have performing the task even with this help. ${ }^{2}$ We consider a respondent to have residual disability if they report at least some difficulty even with help/use of equipment or if they report that they do not receive help/use equipment but do have difficulty with the task.

The difference between intrinsic and residual difficulty is termed coping. Specifically, we define coping as the share of the population with intrinsic disability who

\footnotetext{
1 Specific questions are: "Because of physical, mental, or emotional problem do you get help from another person ..." and "Because of a physical, mental or emotional problem do you need to be reminded to do or need to have someone close by to do them" for ADL tasks and "Because of a physical, mental or emotional problems do you get help or supervision from another person," for IADL tasks.

${ }_{2}$ The response options for this question are no difficulty, some difficulty, a lot of difficulty or completely unable.
} 
do not have residual disability (i.e., the fraction of people for whom disability is completely resolved through the use of special equipment or help from another person).

There are many data sets that ask about either intrinsic disability (for example the National Long Term Care Survey (NLTCS), the Medicare Current Beneficiary Survey (MCBS) and all years of the National Health Interview Survey (NHIS)). However, there are only a few data sets that ask about residual disability ${ }^{3}$ and to our knowledge only three data sets that asks about both intrinsic and residual disability - the NHIS-D, the 1993 AHEAD and First National Health and Nutrition Examination Survey (NHANES I) Epidemiologic Followup Study (NHEFS). ${ }^{4}$ We chose not to use the NHEFS because the data were collected in the 1980s and included only approximately 10,000 individuals. While the HRS/AHEAD data contains more detailed information on socioeconomic measures than the NHIS, we chose to use the NHIS-D in our analysis for several reasons. First the sample size is substantially larger for the 1994-1995 NHIS-D (almost 25,000 respondents age 65 and older compared to approximately 8,000 respondents to the 1993 AHEAD). Second, the AHEAD data only contains information on residual disability in

\footnotetext{
${ }^{3}$ For example, Verbrugge and Sevak (2002) also used residual disability measures in the NHIS-D to study the efficacy of various types of assistance; Verbrugge et al (1997) used measures of residual disability in the NHANES I; and Taylor and Hoenig (2004) and Agree (1999) studied residual disability using the Asset and Health Dynamics Among the Oldest Old (AHEAD). Several investigators have also examined coping with disability using other outcomes. For example, Agree and Freedman (2003) examined pain, fatigue and time intensity associated with tasks even when using help using the NHIS-D Phase 2 surveys and Penning and Strain (1994) examined subjective feelings of well-being among using of assistance with daily tasks.

${ }^{4}$ The 1993 AHEAD asks a similar set of questions about intrinsic and residual disability in ADLs as the NHIS-D. Specifically respondents were first asked, "Does anyone ever help you ...," then for two of the ADLs (getting around inside and getting in and out of bed), respondents were asked, "Do you ever use equipment or devices when ...." Respondents who report the use of either personal assistance or special equipment were then asked, "Even when someone helps you/using the equipment, do you have any difficulty ..." Finally, respondents who deny personal or equipment help were asked, "Without any help or special equipment, do you have any difficulty ..." In contrast, the NHEFS first asked about difficulty with 12 everyday tasks without assistance, "Please tell me if you have no difficulty, some difficulty, much difficulty, or are unable to do .... at all when you are by yourself and without the use of aids." Those reporting much difficulty or being unable to do the task were then asked about assistance from another person or help from special equipment and those using assistance were asked about degree of difficulty when they used the assistance.
} 
ADL measures, while the NHIS-D asked respondents about difficulty with help for ADL and IADL tasks. Finally, the AHEAD only asked respondents about the use of special equipment to aid in the performance of two of the ADL tasks.

The NHIS-D was conducted in 1994 and 1995 as a supplement to the regular National Health Interview Survey. The survey was administered in person at the same time as the NHIS Core and collected information on all members of the household age 5 and over. Several limitations of the NHIS-D should be noted. First, the NHIS is restricted to people living in the community. Disability rates are thus lower than those found in surveys that include institutionalized individuals (such as the NLTCS or the MCBS). Our analysis will not take into account SES differences in the likelihood of nursing home use. As residence in a nursing home suggests inability to cope with declining health and disability, our analysis may underestimate SES differentials in the ability to cope with disability.

Second, the NHIS-D contains imperfect measures of household income. Household income was measured in the 1994 and 1995 NHIS through two survey questions. First respondents were asked if their family income was lower or higher than $\$ 20,000$. Then respondents were asked to categorize their income into 27 income groups. The detailed categories were not reported by approximately $20 \%$ of respondents in our sample. ${ }^{5}$ For these respondents, the NCHS imputed family income using sequential hot deck imputation within matrix cells. ${ }^{6} \quad$ Because of these measurement issues, and

\footnotetext{
${ }^{5}$ The weaknesses in this approach to assessing household income become apparent by contrasting it to the approach taken in the HRS. For example, while $45 \%$ of responding households to the 1993 AHEAD refused to report their exact household income, $75 \%$ of these respondents completed an unfolding cascade while an additional $11 \%$ completed some of the unfolding cascade so that household income was completely missing for only $6 \%$ of the households.

${ }^{6}$ The imputation was aided by detailed income and wealth data collected in the Family Resource Supplement. Specifically, respondents age 65 and over were cross-classified according to total monthly
} 
because household income may not adequately reflect resources and assets in an elderly retired sample, we focus our primary attention on the relationship between coping and education, noting that our estimates of the relationship between household income, disability and coping are inherently limited by the available data.

The NHIS-D also collects data on difficulty with several measures of physical functioning: lifting something as heavy as 10 pounds, walking up 10 steps without resting, walking a quarter of a mile, standing for about 20 minutes, bending down from a standing position to pick up an object from the floor, reaching up over the head or reaching out as if to shake someone's hand, using fingers to grasp or handle something, and holding a pen or pencil, and the use of specific assistive technologies (not in conjunction with ADL or IADL tasks) including canes, crutches, walkers, orthopedic shoes, manual and electric wheelchairs, scooters, and braces. Sociodemographic variables include information on respondents' age, race, gender, marital status, educational attainment and household income, taken from the core survey. All analyses accounted for the complex survey design and for pooling data from both survey years using approximations based on Taylor-series linearizations. ${ }^{7}$

\section{Descriptive Statistics}

family income reported in the Family Resources Supplement and median household income in their sampling segment. Within these cells respondents were then sorted according to marital status, educational attainment, gender and race-ethnicity for respondents who indicated their household income was less than $\$ 20,000$ and according to educational attainment, hours worked per week, marital status and number of adult workers in the family for those who reported their income to be over $\$ 20,000$. Hot-deck imputation was then implemented within these sorted cells. For more details see, "Methods used to impute annual family income in the National Health Interview Survey, 1990-96."

http://www.cdc.gov/nchs/products/elec_prods/subject/impute.htm. Last accessed May Dec 22, 2005.

${ }^{7}$ For details see, "Variance estimation for person data using Sudaan and the National Health Interview Survey (NHIS): Public use person data files, 1994-1995: Combining '94 and '95 data only."

http://www.cdc.gov/nchs/data/nhis/94_95var.pdf. Last accessed Dec 22, 2005 
We start our empirical analysis with basic data on disability. Although the NHIS$\mathrm{D}$ is administered to people of nearly all ages, we focus on the elderly population (ages 65 and older), since ADL and IADL disability rates are much higher in the elderly than in the non-elderly. This also allows us to compare our results with most of the existing literature, which has focused predominantly on the elderly population. In two years of administration, the NHIS-D collected data on 24,791 people aged 65 and older.

Table 1 presents basic descriptive data on the population. Fifty-eight percent of the population is female and 89 percent is white. Fifty-seven percent of the population is married, and a third is widowed. The education distribution is skewed towards less completed schooling. Twenty-two percent of the sample did not start high school. Another fifteen percent started high school but did not finish. Modal income is between $\$ 10,000$ and $\$ 20,000$.

Table 2 shows data on disability and coping rates. Nearly 10 percent of the population reports some intrinsic ADL disability. This rate is comparable to other surveys that have asked about intrinsic disability among community dwelling elderly. For example, rates of ADL disability, defined as the getting help or using special equipment with one or more ADL, among community-dwelling elderly age 70 were approximately 15 percent in the 1995 HRS and the 1994 NLTCS and slightly over 20 percent in the 1994 MCBS (Freedman et al 2004). Over six percent of the respondents report residual disability (difficulty completing the task even with help or special equipment) on at least one ADL, meaning that approximately one-third of the elderly population effectively copes with an underlying health problem so that all of their ADL 
limitations are resolved through the use of help or equipment. ${ }^{8}$ Looking within categories, the most common ADL impairment is difficulty bathing ( 7.7 percent) and the least common is difficulty eating (1.4 percent). The other measures are relatively similar, at about 4 percent each. Coping rates vary less across the tasks, ranging from $25 \%$ for transferring to $39 \%$ for bathing.

A much larger share of the population - nearly one-quarter - reports an intrinsic IADL disability. The ability to cope with IADL disability is smaller; only one-quarter of people report that help completely alleviates their difficulty in performing important tasks required for independent living. By a wide margin, the most common IADL disability is doing heavy housework (22 percent). Activities associated with lighter housework or shopping are second in importance ( 7 to 10 percent). Coping rates are again not particularly different across the various categories, ranging from $26 \%$ for light housework to $37 \%$ for managing money.

Figure 1 presented the relation between socioeconomic status and residual disability. Figure 2 presents the complementary figure for intrinsic disability. As with residual disability, intrinsic disability is substantially different by income and education. The highest education group has an intrinsic disability rate for ADLs that is approximately one-half as large as the lowest education group. The variation across income groups is slightly smaller, but still large. There is large variation in IADL disability both by income and education.

\footnotetext{
${ }^{8}$ Verbrugge and Sevak (2002) found similar levels of coping across ADL and IADL tasks among NHIS-D respondents age 55 and older. These rates can also be compared to those reported by Agree (1999) in an analysis of the 1993 AHEAD. She found that $68 \%$ of respondents with ADL disability reported residual difficulty performing tasks. Verbrugge et al (1997) analyzing data from the NHANES I Epidemiologic Followup Study found that assistance (either personal or equipment) resolved difficulty in about $25 \%$ of those with functional limitations and/or disability.
} 
The key issue for coping is the difference between intrinsic and residual disability. Figure 3 shows how coping varies by income and education. There is little variation in ability to cope with ADL impairments by income (Figure 3a). Only the highest income group has higher rates of coping than the average, and the second highest group has the lowest rates of coping. Coping ability generally increases with education, with the exception of the best educated group. Thirty-nine percent of those with some college cope with intrinsic ADL disability, compared to only 27 percent of the less well educated. The story is similar for coping with IADL impairments (Figure 3b). There is little variation in coping with IADL impairments across income groups, and a pronounced education gradient in coping.

Figures 4 and 5 show income and education gradients in coping, according to task. Education gradients in ADL coping are most pronounced for coping with difficulties eating and dressing. This is interesting given that these are areas where use of equipment is very minor, but use of personal help is much greater (shown in Table 7 below). Education gradients in coping with IADL disabilities are largest for light and heavy housework - again areas where personal help, especially paid help, can be very important. In contrast, there are few differences across income and education groups in coping with difficulties managing money, grocery shopping, and using the telephone.

While Figures 1 through 3 are age and sex adjusted, we also want to control for other demographic differences across groups. Table 3 reports basic regression results for intrinsic disability and Table 4 shows results for residual disability. The first regression in each table is for any disability - either ADL or IADL impairment; the second and third regressions are for any ADL and IADL disability separately. In addition to five year age 
and sex groups and their interaction and the income and education dummy variables, we include controls for marital status (married, widowed, or separated/divorced/single) interacted with gender, and race (white or non-white).

Older and non-white respondents are more likely to report disability and women are more likely to report IADL disability. There is little indication that age effects varied by gender of the respondents. Single people, whether widowed or divorced/separated/never married, have higher rates of disability than do married people. Surprising, this effect is similar for men and women. Including these demographic variables has little impact on the education and income results. For example, the difference in residual ADL disability between the best educated and the least educated in Figure 1 is 4.1 percentage points; the difference in table 4 is 3.8 percentage points. In the case of residual IADL disability, the unadjusted difference is 7.7 percentage points, and the adjusted difference is 5.6 percentage points. Our findings are thus not an artifact of demographic differences in the various groups.

Table 5 shows how coping differs by income and education, controlling for demographic factors and the severity of the underlying disability as measured by the number of reported limitations. Ability to cope is strongly negatively related to the number of limitations. In contrast to intrinsic or residual disability, there are few differences across demographic groups in coping with disability ${ }^{9}$. Similar to the age and sex adjusted results presented in Figure 3, we find differential effects in coping by education but not by income. Coping with ADL disability is 4 to 10 percentage points

\footnotetext{
${ }^{9}$ This is similar to results presented in Verbrugge and Sevak (2002) who find that need characteristics, such as severity of disability and poor health status, explain as much as $30 \%$ of the variance in resolving difficulty with ADL and IADL tasks while predisposing and enabling characteristics, such as age, race, marital status and socioeconomic status, are much smaller factors in explaining ability to cope with disability.
} 
higher among all respondents with at least some high school compared to those who never started high school, with the highest rates of coping (38 percent) among those with some college education. Coping with IADL disability is about 5 percentage points higher among college graduates compared to those with a high school degree or less.

Because there may be differences in the relationship between coping with disability and socioeconomic status according to gender, we examined differences in coping separately by women and men. Figure 6 displays differences in coping by education and income in men and women (full regression results reported in Tables A and $\mathrm{B}$ in the appendix). In contrast to combined results in men and women, there are income differentials in coping among men, particularly at the highest levels of income. Coping rates are 11 percentage points higher among men with family incomes $\$ 50,000$ and over compared to those with incomes under $\$ 10,000$. Differences in coping by level of education are only evident among women, although the small number of males in our sample limits our power to detect these associations. Coping rates are 4 to 8 percentage points higher in women with at least a high school diploma compared to women with less than high school education.

We have also examined the impact of estimating models for disability including income and education separately. Tables B through $\mathrm{G}$ in the appendix show the impact of income and education when the other variable is excluded from the model, for each of intrinsic disability (Tables B and C), residual disability (Tables D and E), and coping (Tables F and G). Comparing the Appendix tables to the equivalent regressions in Tables 3 through 4 shows that for IADL disability, gradients in income and education are largely independent of each other. This may seem surprising but is relatively common in health 
studies, where income and education often pick up very different effects (Deaton and Paxson, 2001). In the case of ADL disability, income by itself has an effect on disability that is almost entirely explained by education when both are included in the model. Income has very little effect on effective coping with disability even in the absence of education in the model. Our results suggest that among the elderly, education is a more fundamental marker of socioeconomic status than is income (or at least income measured with error ${ }^{10}$. We present results with income and education included in the same equations throughout the rest of the paper.

\section{How Do the Better Educated Cope?}

The central question raised by our results is how the better educated manage to cope with intrinsic disability. The first hypothesis we consider is that our results simply reflect difference in unmeasured health by educational attainment. While we examined residual disability in the sub-set of respondents with intrinsic disability and controlled for the number of reported limitations, it may be that more educated respondents have less severe intrinsic disability that is more easily resolved.

We test this hypothesis by including an additional set of controls in our models representing difficulty performing a set of 7 physical tasks: lifting something as heavy as 10 pounds (15 percent of the elderly report difficulty with this task), walking up 10 steps without resting (19 percent), walking a quarter of a mile (25 percent), standing for about 20 minutes (18 percent), bending down from a standing position to pick up an object

\footnotetext{
${ }^{10}$ This is in contrast to results presented by Agree (1999). Analyzing data from the 1993 AHEAD, she finds that residual disability among respondents with limitations in getting around inside the home has a non-linear relationship with net worth, so that residual disability declines with net worth up to a certain point and then increases with increasing net worth. Education has a small and marginally significant relationship with residual disability.
} 
from the floor (17 percent), reaching up over the head or reaching out as if to shake someone's hand ( 8 percent), using fingers to grasp or handle something (6 percent). The results from these models are presented in Table 6.

Comparing estimated effects in Tables 5 and 6 we find some evidence for this hypothesis, although it is not the whole explanation. For example, about a quarter of the difference between those with a college education in coping with IADL disability is explained by better underlying physical functioning, and the effect is no longer statistically significant. Better health explains less of the education differences in coping with ADL disability, but it is still some of it. Because we find that differences in physical functioning explain some of the observed gradient, we include controls for functional status in all future regressions.

Our second hypothesis concerns differences in the use of various coping strategies. The NHIS-D provides information on two broad coping strategies. The first strategy is getting help from other individuals. The survey asks respondents who report help from another person in completing an ADL or IADL task whether they received help from relatives or non-relatives ${ }^{11}$ and whether or not these helpers where paid. ${ }^{12} \mathrm{We}$ classify personal help into three groups: 1) help from a spouse, child or parent, 2) other unpaid help, or 3) paid help. ${ }^{13}$ The second strategy is to use assistive technologies. Respondents were asked about the use of "special equipment" to aid in ADL tasks.

\footnotetext{
${ }^{11}$ The survey also distinguishes between household members and non-household members.

${ }^{12}$ Respondents are not asked about paid help if they report receiving help from a spouse, child or parent only.

${ }^{13}$ We initially considered unpaid help from relatives and non-relatives separately. However, since only a small number of respondents report unpaid help from a non-relative (4\% and $6 \%$ of those with ADL and IADL disability respectively), we combined the two categories.
} 
Table 7 shows the use of various coping strategies used by those who report intrinsic disability in different domains. A vast majority of people (approximately 90 percent) with disability use at least one of the coping strategies. Overall, 64 percent of people with any ADL impairment use personal help - 22 percent receiving help from a spouse, child or parent, 21 percent using other unpaid help, and 25 percent using paid help - and 56 percent use assistive technology.

Coping strategies are very different across domains. Very few elderly use assistive technology to help with eating and dressing. For example, 81 percent of people with trouble eating use help from other people, and less than 10 percent use assistive technology. In contrast, approximately half of those with intrinsic disability in toileting or getting around inside use personal help, while over 60 percent use assistive technology.

Only questions about personal help are asked for people who report IADL disability. Across domains, reported use of help is high, ranging from 83 percent for using the telephone to 93 percent for managing money.

Coping strategies also differ by SES group. ${ }^{14}$ Tables 8 and 9 show regression results for the use of different coping strategies by income and education, and Figures 7 and 8 display adjusted percentages of people using each type of help. The use of any personal help for ADL disability increases with income. Use of personal help is 16

\footnotetext{
${ }^{14}$ The prior literature on the effect of income and education on use and types of assistance is mixed (see Agree et al 2004 and references there in). Most of this literature suggests that the predominate factor in determining use of assistance and types of assistance among those who use some assistance is need (ie severity and number of limitations and other measures of underlying health). For example, Verbrugge and Sevak (2002) found that need characteristics, such as degree of difficulty and number of limitations, explained $27 \%$ of the variation in use of assistance among those with ADL disability while predisposing and enabling characteristics, such as age, race, marital status, education and income explained only $6 \%$ of variation in use of assistance. Similarly, Mathieson et al (2002) found that need characteristics explained $15 \%$ of variation in use of equipment among those with ADL and IADL limitations while enabling characteristics explained only $2 \%$ of variance.
} 
percentage points higher (76\% versus $60 \%$ ) in the group with income above $\$ 50,000$ than the group with income below $\$ 10,000$ (data not shown). Despite their higher incomes, the rich use paid help much less than the poor for both ADL and IADL disabilities. But they offset the reduced use of paid help with substantially more help from close relatives. This is consistent with the 'strategic bequest' model of Bernheim, Shleifer, and Summers (1985); the possibility of an inheritance may spur children of better off parents to provide more direct assistance (of course, other hypotheses are possible as well). Use of assistive technologies for help with ADL disability is relatively independent of income.

The pattern is the reverse for education. The better educated use more paid help than the less educated, but receive less help from close relatives. All told, the better educated use less personal care than the less educated (particularly for ADL tasks). For ADL tasks, the better educated offset their lower use of personal care with substantially higher rates of use of assistive technologies. On net, use of any form of help is high among all respondents and roughly equal by education and income.

The important question is how differential use of these technologies is related to the ability to cope with impairment. We examine this issue by including measures of personal and assistive technology use in the equations for ability to cope with disability. Since respondents who use neither personal help nor equipment but report difficulty by definition have residual disability, we focus on the subset of respondents who use some kind of help (either personal or equipment). This omits only about 10 percent of the sample. $^{15}$

\footnotetext{
${ }^{15}$ There is unlikely to be any bias from this, as the analysis reported in the last columns of Tables 8 and 9 already demonstrated that education had little effect of whether or not respondents used any help.
} 
The results of this analysis are shown in Table 10 for ADL impairment and Table 11 for IADL impairment. We report estimated effects without controlling for use of equipment and personal help in the first two columns in each table. These results differ from those reported in Table 6 because of the restriction to the sample of respondents who use either personal help or equipment. For these models we use mutually exclusive categories for the type of help received. For ADL disability these categories are equipment only (29\%), help from a spouse, child or parent only (14\%), other unpaid help only (6\%), paid help only (8\%), multiple types of personal help (9\%), and use of equipment and personal help (30\%). For IADL disability the categories are help from a spouse, child or parent only (29\%), other unpaid help only (18\%), paid help only (24\%), and multiple types of personal help (30\%). In each case, the omitted category in the regression models in other unpaid help only. Relative to this category, people who use multiple types of personal help are better able to cope with both ADL and IADL disability. Help from a close relative is also less effective than other unpaid help for coping with IADL disability, perhaps reflecting the fact that family members who have less formal knowledge and training with disabled people are less effective at helping to resolve disability.

Surprisingly, including measures of use of personal and assistive technologies does not affect the income or education coefficients in any material way. Comparing the two columns in Table 10 shows that the coefficients on the higher education groups are somewhat larger in the models with all of the help variables included as in the models without the help variables. For example, the gap in coping with ADLs between those with some college and those with less than a high school degree is 8.4 percent without the 
measures of help, and 9.0 percent with measures of help. Controlling for the types of help received for IADL disability (reported in Table 11) explains more of the relationship between education and coping. However, these effects were small and not statistically significant even in the absence of controls for types of help received.

The NHIS-D did not ask about the use of equipment to aid IADL tasks but did ask all respondents (regardless of whether or not they reported disability) about use of specific mobility aids including a cane or crutch, a walker, a manual wheelchair, an electric wheelchair or scooter, or a brace. In the fifth and sixth columns of Table 11, we present a model that also controls for the use of these specific mobility aids. While use of an electric wheelchair or scooter was a more effective coping strategy than other mobility aids (or the use of no mobility aids), use of specific technologies does not have any additional explanatory power once we control for differences in the types of personal help received.

Because both the use of coping strategies and their effectiveness may vary by gender, we also examined coping controlling for the use of help separately in men and women. Table 12 shows rates of use of various coping strategies by gender. Over $50 \%$ of men and women use equipment for ADL tasks. Men are more likely to get personal help with ADL tasks (69\% vs. 62\%), particularly help from a spouse, child or parent ( $31 \%$ vs. $18 \%$ ). However, women are more likely to obtain paid help than men (28\% vs. $21 \%$ ), and there are few differences in use of other unpaid help for ADL tasks. For IADL tasks, differences across gender in help from family members and paid help are smaller. For example, $27 \%$ of men obtain help from a spouse, child or parent for IADLs compared 
to $25 \%$ for women. However, women are more likely to use other unpaid help for IADL tasks compared to men (29\% vs. $24 \%)$.

We present analysis of coping ability by gender in Tables $\mathrm{H}-\mathrm{K}$ in the appendix. There is little evidence that the effectiveness of coping strategies varies by gender. In addition, patterns observed in combined sample generally hold in each gender. For example, in both men and women, adjusting for types of help increases differences by education in coping with ADL limitations.

Because both coping strategies and the size of the education gradient in coping vary according to specific activity, we also examined whether or not coping strategies explained task-specific education gradients. We examined four particular ADL and IADL restrictions: difficulty getting around inside and dressing (both ADL impairments); and difficulty shopping and doing light housework (IADL impairments). Two of these impairments seem particularly amenable to help from assistive technology, particularly mobility aids - getting around inside and shopping. The other two are activities where there are strong education gradients in coping ability, shown in Figures 4 and 5.

Table 13 shows the impact of coping strategies on coping with these two ADL difficulties and Table 14 shows comparable results for the IADL difficulties. In each case, the first two columns report results without the coping measures, and the next two columns displays results controlling for the coping measures. ${ }^{16}$ Once again, use of coping strategies does not explain the better coping of higher education groups with

\footnotetext{
${ }^{16}$ Questions about the type of help received were not asked in regard to specific tasks, so we cannot differentiate between respondents who use multiple types of help for each of their limitations from a respondent who uses paid help for some tasks and gets help from a spouse for other. Thus for ADL disability we collapse our categories for type of help into equipment and personal help, equipment only and personal help only. In addition, since respondents with IADL disability were not asked about equipment help, we control for specific mobility aids in models examining specific IADL tasks.
} 
specific ADL or IADL tasks. Surprisingly, type of coping strategy or use of specific mobility aids had little effect on ability to cope with specific task, and thus had little effect of the impact of education and income.

\section{Conclusion}

Analyses of socioeconomic gradients in health are notoriously difficult, and ours turns out to be complex as well. We show that the better educated are better able to cope with underlying disability than the less educated. These differences are large: the ability to cope with disease varies by as much as 8 percentage points across education groups. We also show that the type of help different education groups receive is different. The better educated are more likely to use assistive technologies than the less educated, and are more likely to receive paid help than help from close relatives. Despite our best attempts, however, we are unable to show that it is the use of these different forms of aids that explains differences in the ability to cope.

With the data that we have, we cannot examine this puzzle more completely. But there are several hypotheses that might be tested using other data. One hypothesis is that the more educated use care more intensively. For example, among users of paid help, the less educated might use two hours of paid care per week, while the better educated might use four hours. The additional two hours could substantially reduce impairment, but we cannot determine that with our data. Several other researchers have observed sociodemographic differences in the intensity of personal care. For example, Weiss et al (1995) analyzed data from the 1993 AHEAD and found that Hispanics received more hours of informal care per week than African Americans and non-Hispanic whites. 
Kemper (1992), in a small study of highly disabled individuals, found that income was positively associated with both the likelihood of receiving paid help and the number of hours of help among users of paid help. Those who completed high school were also more likely to use paid help, but not more hours of help conditioning on using any paid help.

A related hypothesis is that the quality of the care received might be higher for the more educated compared to the less educated. The personal help received could be better trained and the equipment might be newer or less subject to failure.

A third hypothesis is that the more educated may be more willing or able to use behavior and environmental modifications to cope with their disability. For example, the more educated might be more likely to cope with difficulty in preparing meals by buying prepared foods, or they might be more able to make home modifications that allow them to function with their disability. Few surveys collect data on the use of behavior modifications and environmental adaptations. Norburn et al, (1995), analyzed data from the 1991 National Survey of Self-Care and Aging and estimated that $75 \%$ of the community elderly coped with their loss of functioning by changing their behavior, while one-third made adaptations in their environment. Surprisingly, they found that these coping strategies were not associated with income or education. Similarly, Mathieson et al (2002), analyzing the National Survey of Self-Care and Aging, found that household income and education were not related to the likelihood of making home modifications, although subjective measures of resources, such as reporting having enough income to buy little extras did increase the likelihood of making home modifications. 
A final hypothesis is that the environments that the more educated live in are more conducive to use of technology or personal aids. If the better educated live in homes or shop in stores where there is more space, ramps, and elevators, use of a wheelchair may be able to fully resolve the underlying impairment. That might be less true in a crowded house or a store with narrow aisles and steps. Data on the specific physical features of the home or environment are limited. However, Gitlin et al (2001) reported an average of 13 environmental problems in a small study of approximately 300 elderly. Similarly, analyzing data from the 1995 American Housing Survey, Sandra Newman (2003) found that $23 \%$ of elderly individuals had unmet need for housing modifications and the number of reported unmet needs was negatively associated with household income.

In summary, we find that while the majority of socioeconomic differences in disability can be attributed to differences in underlying functioning - the better off have much less difficulty with these measures even in the absence of help - coping is important as well. In addition, while we find differences in the way people receive help with functional limitations across educational and income groups, these differences do not explain the education gradient in coping. More work is needed to disentangle the complex interrelationships between underlying functional limitations, coping strategies and the environment in which people live in order to further understand how the better educated are better able to cope with underlying disability. 


\section{References}

Agree, Emily M. 1999. The influence of personal care and assistive devices on the measurement of disability. Social Sciences and Medicine 48:427-443.

Agree, Emily M. and Vicki A. Freedman. 2003. A comparison of assistive technology and personal care in alleviating disability and unmet need. The Gerontologist 43(3):335344.

Agree, Emily M., Vicki A. Freedman, and Manisha Sengupta. 2004. Factors influencing the use of mobility technology in community-based long-term care. Journal of Aging and Health 16(2):267-307.

Adler, Nancy E, Thomas Boyce, Margaret Chesney, Susan Folkman, and Leonard Syme. 1993. Socioeconomic inequalities in health: No easy solution. Journal of the American Medical Association 269 (24): 3140-3145.

Barker, David J.P. 1994. Mothers, babies, and disease in later life. London: BMJ Publishing Group.

Bernheim, B. Douglas, Andrei Shleifer, and Lawrence Summers. 1985. The strategic bequest motive. Journal of Political Economy 93:1045-1076

Case, Anne, Darren Lubotsky, and Christina Paxson. 2002. Economic status and health in childhood: The origins of the gradient. American Economic Review 92(5): 1308-1334.

Crimmins, Eileen M. and Yasuhiko Saito. 2001. Trends in health life expectancy in the United States, 1970-1990: gender, racial and educational differences. Social Science and Medicine 52: 1629-1641.

Deaton, Angus and Christina Paxson. 2001. Mortality, education, income and inequality among American cohorts. In D. Wise (ed.), Chicago: University of Chicago Press.

Freedman, Vicki A., Eileen Crimmins, Robert F. Schoeni, Brenda C. Spillman, Hakan Aykan, Ellen Kramarow, Kenneth Land, James Lubitz, Kenneth Manton, Linda G. Martin, Diane Shinberg, and Timothy Waidmann. 2004. Resolving inconsistencies in trends in old-age disability: report from a technical working group. Demography 41(3):417-441.

Fried, Linda P. and Jack M. Guralnik. 1997. Disability and older adults: Evidence regarding significance, etiology and risk. Journal of the American Geriatric Society 45:92-100. 
Gitlin, Laura N., William Mann, Machiko Tomit, and Sue M. Marcus. 2001. Factors associated with home environmental problems among community-living older persons. Disability and Rehabilitation 23(17):777-787.

Guralnik, Jack M., Linda P. Fried and Marcel E. Salive. 1996. Disability as a public health outcome in the aging population. Annual Reviews of Public Health 17:22-46.

Kemper, Peter. 1992. The use of formal and informal home care by the disabled eldery. Health Services Research 27(4):421-451.

Mathieson, Kathleen M., Jennie Jacobs Kronenfeld and Verna M. Keith. 2002.

Maintaining functional independence in elderly adults: the roles of health status and financial resources in predicting home modifications and use of mobility equipment. The Gerontologist 42(1):24-31.

McGinness, J. Michael, and William H. Foege. 1993. Actual cause of death in the United States. Journal of the American Medical Association 270:2207-12.

Melzer, David, Grant Izmirlian, Suzanne G. Leveille and Jack M. Guralnik. Educational differences in the prevalence of mobility disability in old age: the dynamics of incidence, mortality and recovery. Journal of Geronotology: Social Sciences 56B(5):S294-S301.

Newman, Sandra. 2003. The living conditions of elderly Americans. The Gerontologist 43 (1):99-109.

Norburn, Jean E. Kincade, Shulamit L. Bernard, Thomas R. Konrad, Alison Woomert, Gordon H. DeFriese, William D. Kalsbeek, Gary G. Koch and Marcia G. Ory. 1995. Self-care and assistance from others in coping with functional status limitations among a national sample of older adults. Journal of Gerontology: Social Sciences 50B(2):S101S109.

Penning, Margaret J. and Laurel A. Strain. 1994. Gender differences in disability, assistance, and subjective well-being in later life. Journal of Gerontology: Social Sciences 49(4):S202-S208.

Schoeni, Robert F., Linda G. Martin, Patricia M. Andreski, and Vicki A. Freedman. 2005. Persistent and growing socioeconomic disparities in disability among the elderly: 1982-2002. American Journal of Public Health 95 (11): 2065-2070.

Stuck, Andreas E., Jutta M. Walthert, Thorsten Nikolaus, Christophe J. Bula, Chritoph Hohmann and John C. Beck. 1999. Risk factors for functional status decline in community-living elderly people: A systematic literature review. Social Science and Medicine. 48: 445-469. 
Taylor, Donald H. and Helen Hoenig. 2004. The effect of equipment usage and residual task difficulty on use of personal assistance, days in bed, and nursing home placement. Journal of the American Geriatric Society 52:72-79.

Verbrugge, Lois M., Catherine Rennert and Jennifer H. Madans. The great efficacy of personal and equipment assistance in reducing disability. American Journal of Public Health 87(3):384-392.

Verbrugge, Lois M. and Purvi Sevak. 2002. Use, type and efficacy of assistance for disability. Journal of Gerontology: Social Sciences. 57B (6):S366-S379.

Weiss, Carlos O., Hector M. Gonzalez, Mohammed U. Kabeto and Kenneth M. Langa. 2005. Differences in amount of informal care received by non-Hispanic whites and Latinos in a nationally representative sample of older Americans. Journal of the American Geriatrics Society 53:146-151.

Zimmer, Zachary and James S. House. 2003. Education, income, and functional limitation transitions among American adults: contrasting onset and progression. International Journal of Epidemiology. 32:1089-1097. 
Figure 1. Share of elderly reporting disability in ADLs or IADLS even with use of help
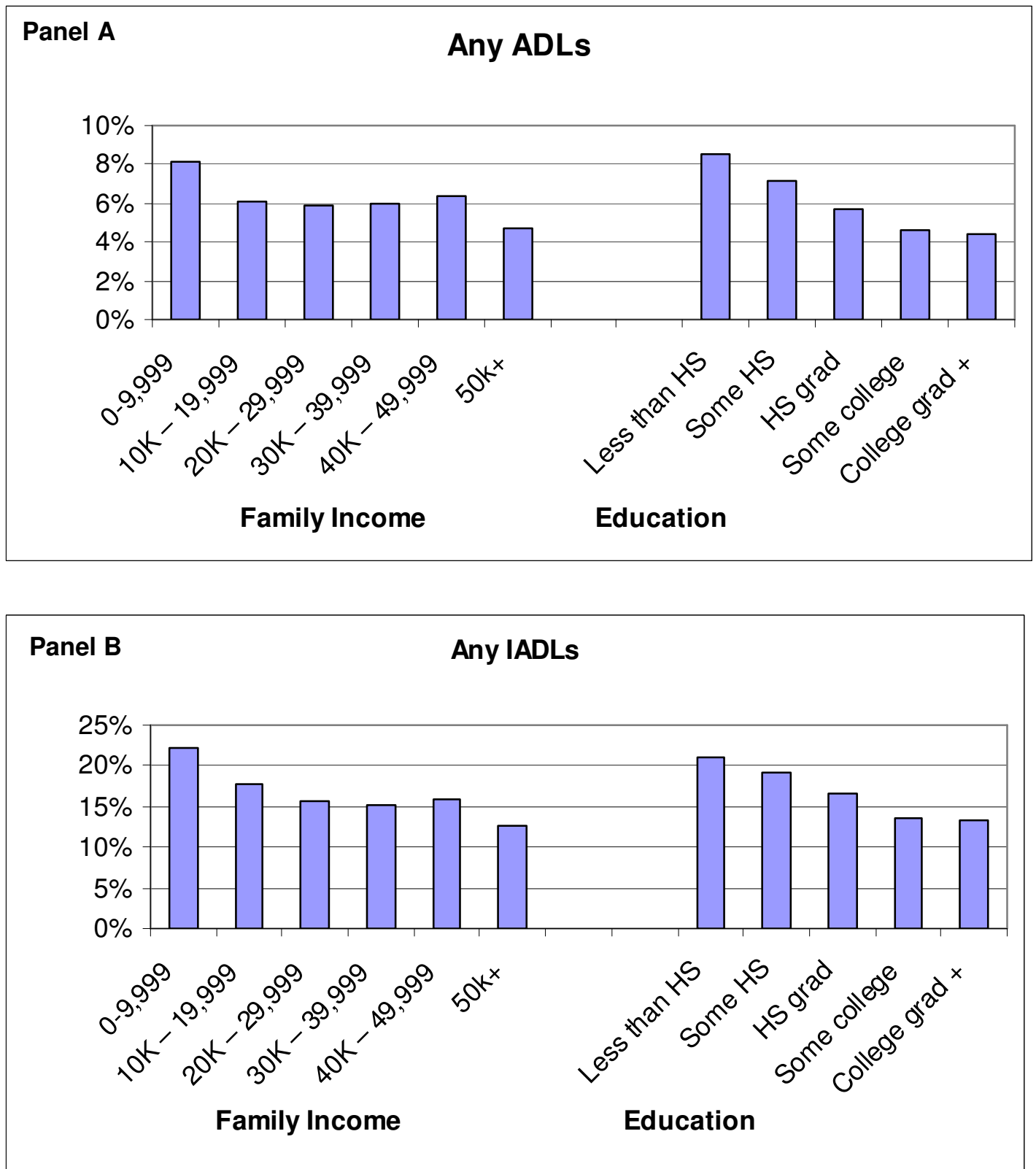

Note: Estimates are adjusted for the age and sex mix of the population. 
Figure 2. Share of elderly reporting disability in ADLs or IADLS in the absence of receiving help
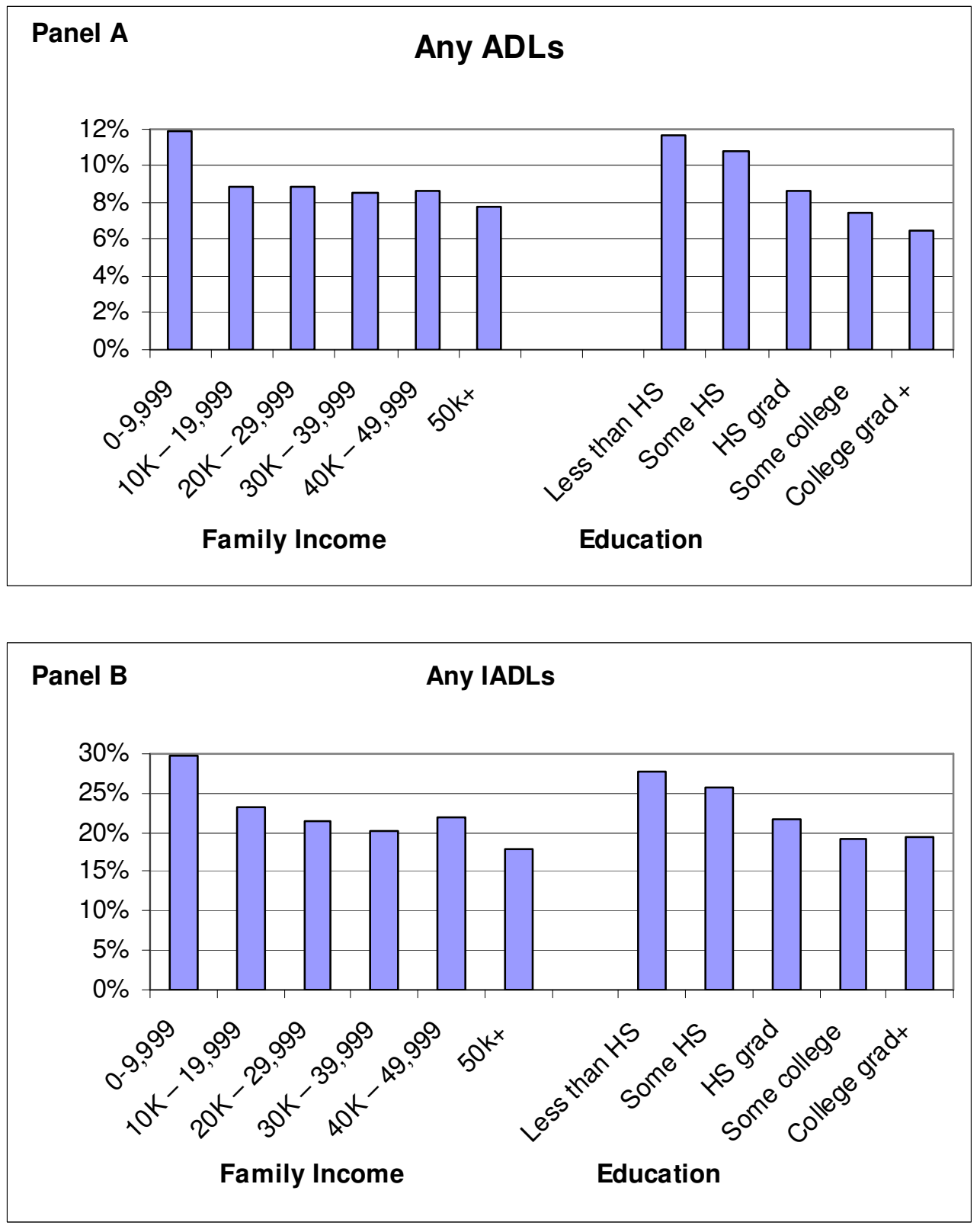

Note: Estimates are adjusted for the age and sex mix of the population. 
Figure 3. Ability to cope for "any ADLs" and "any IADLs" by family income and education, adjusted for age and sex
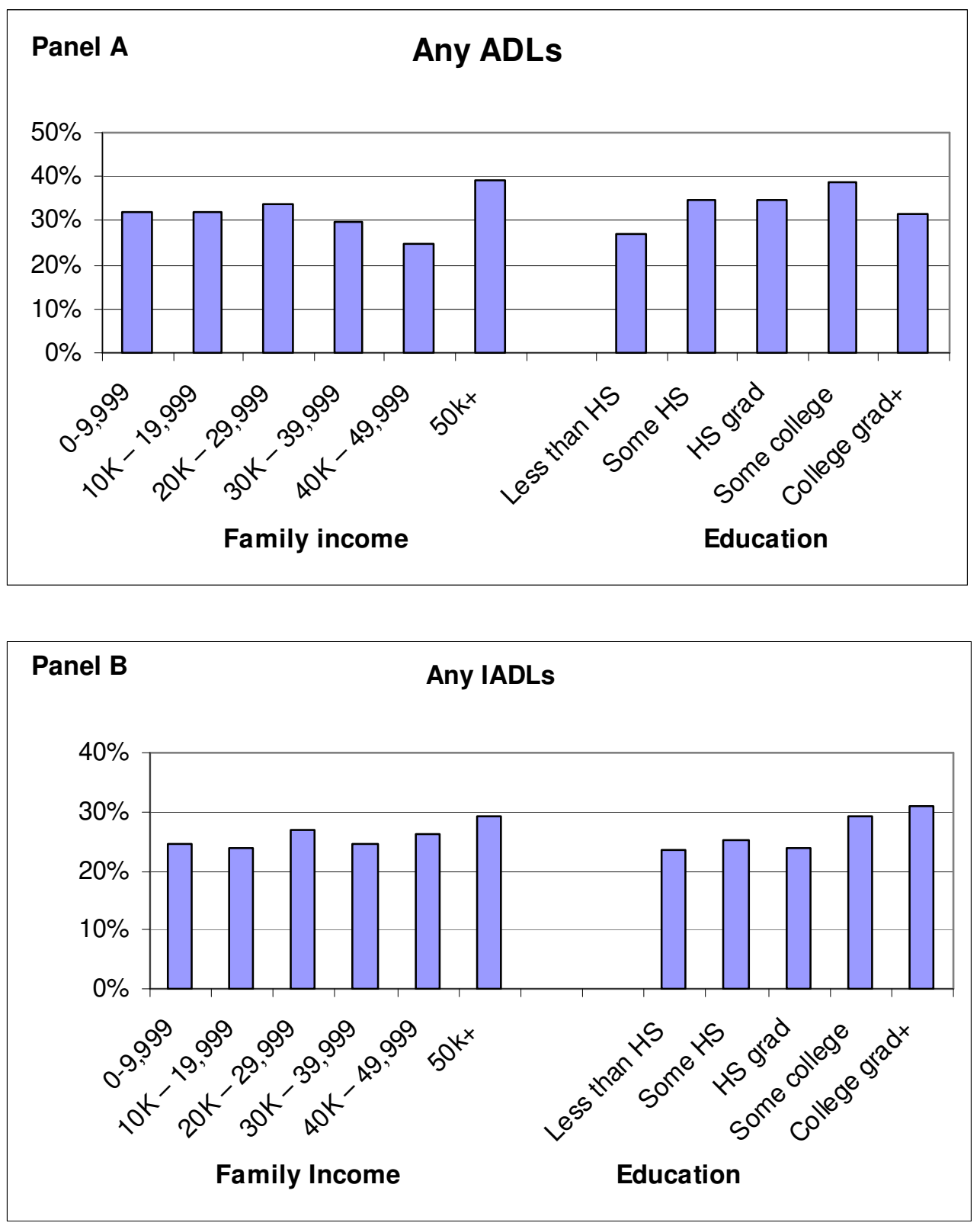

Note: Estimates are adjusted for the age and sex mix of the population. 
Figure 4. Coping ability by specific ADLs
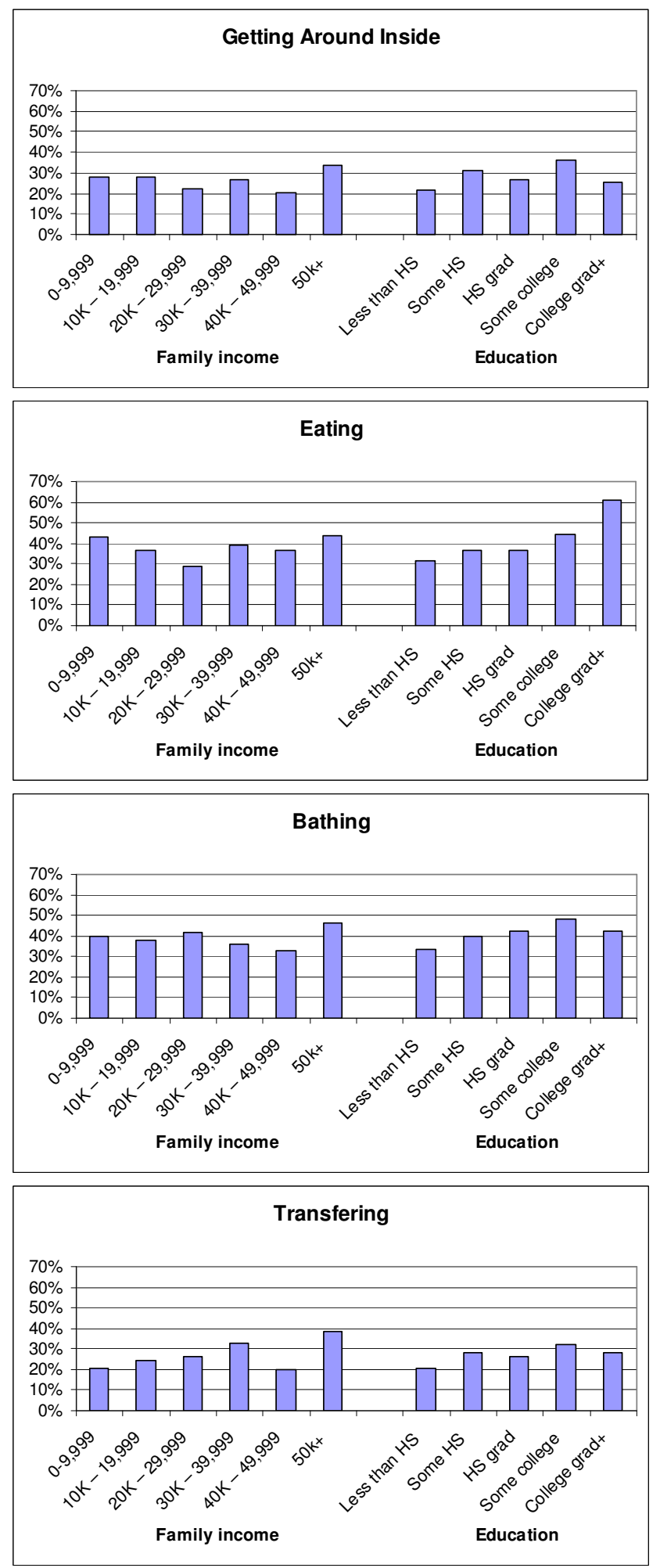

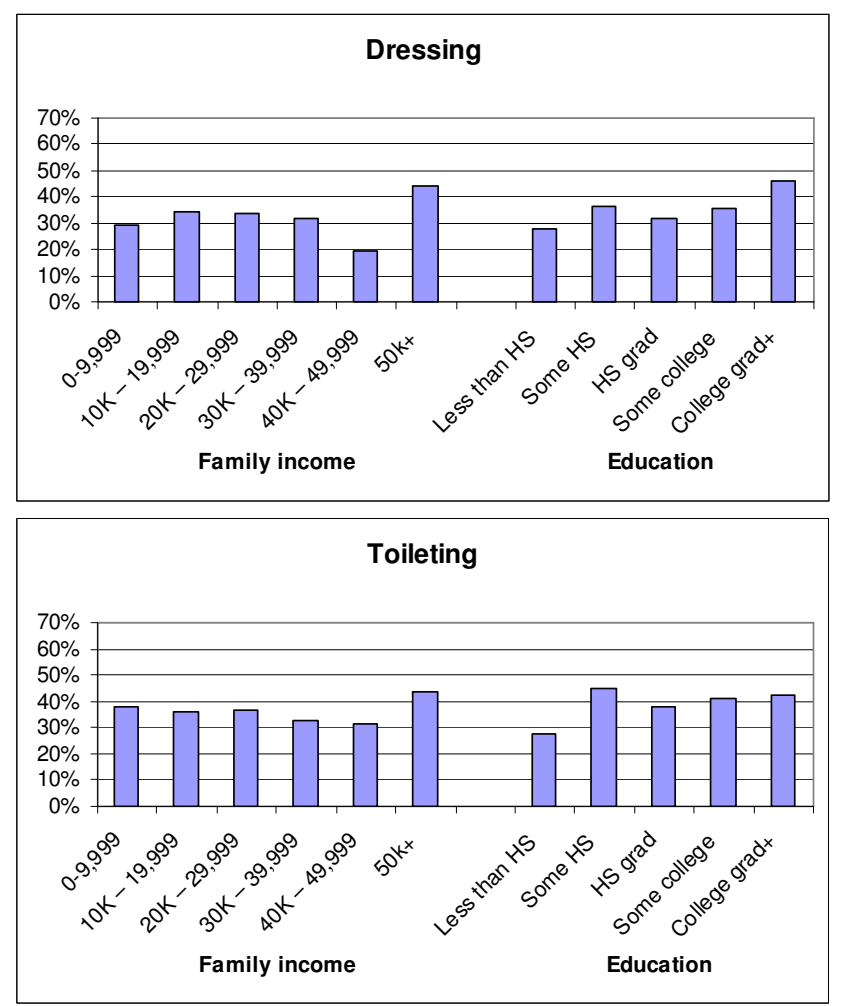

Note: Estimates are adjusted for the age and sex mix of the population. 
Figure 5. Coping ability by specific IADLs
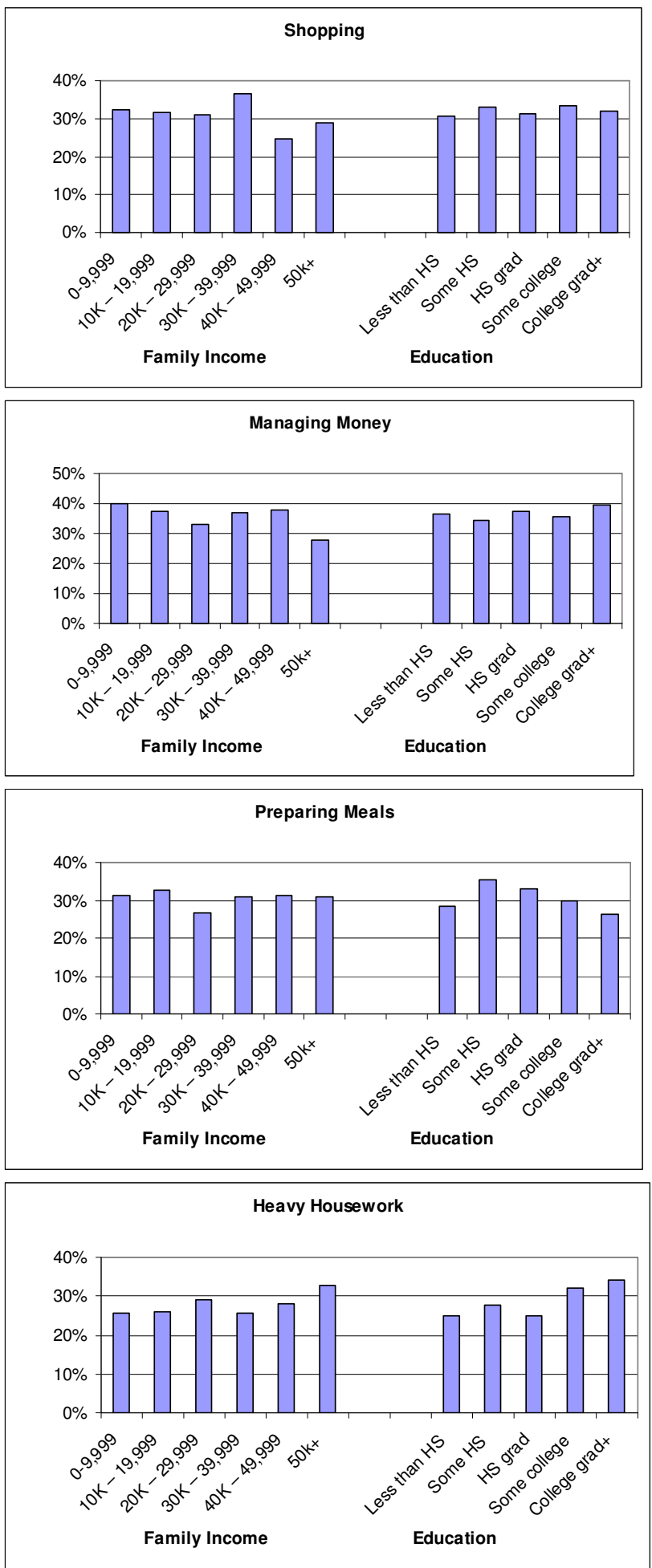

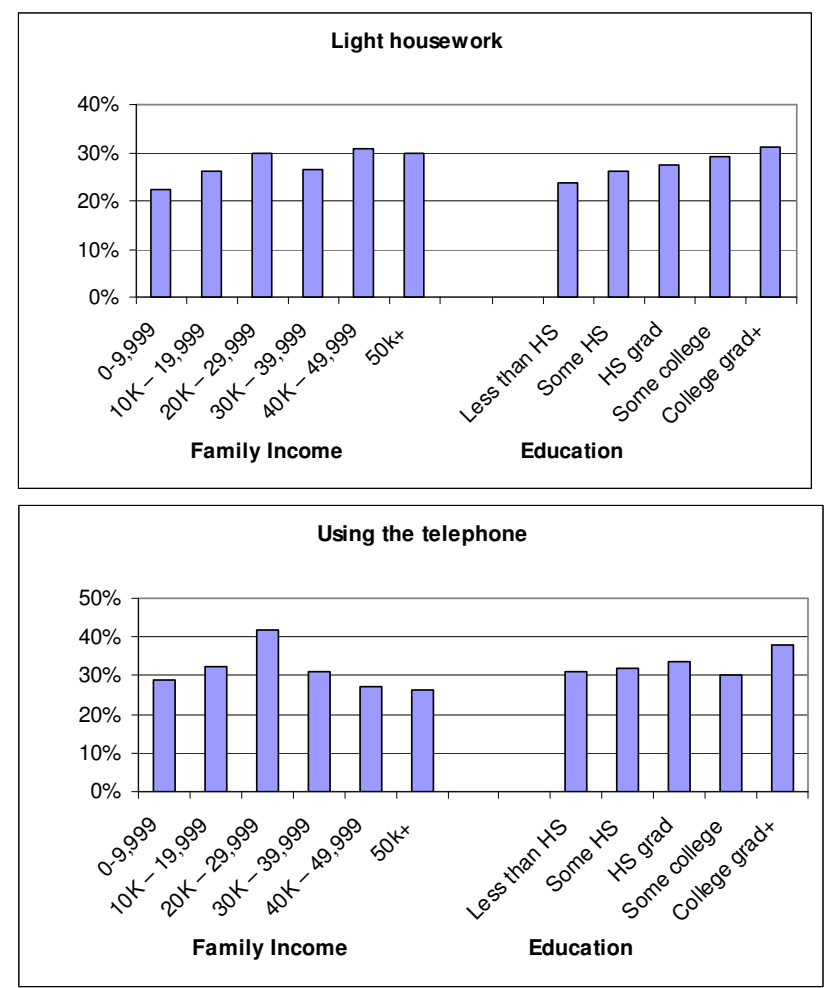

Note: Estimates are adjusted for the age and sex mix of the population. 
Figure 6. Coping ability by gender, income and education
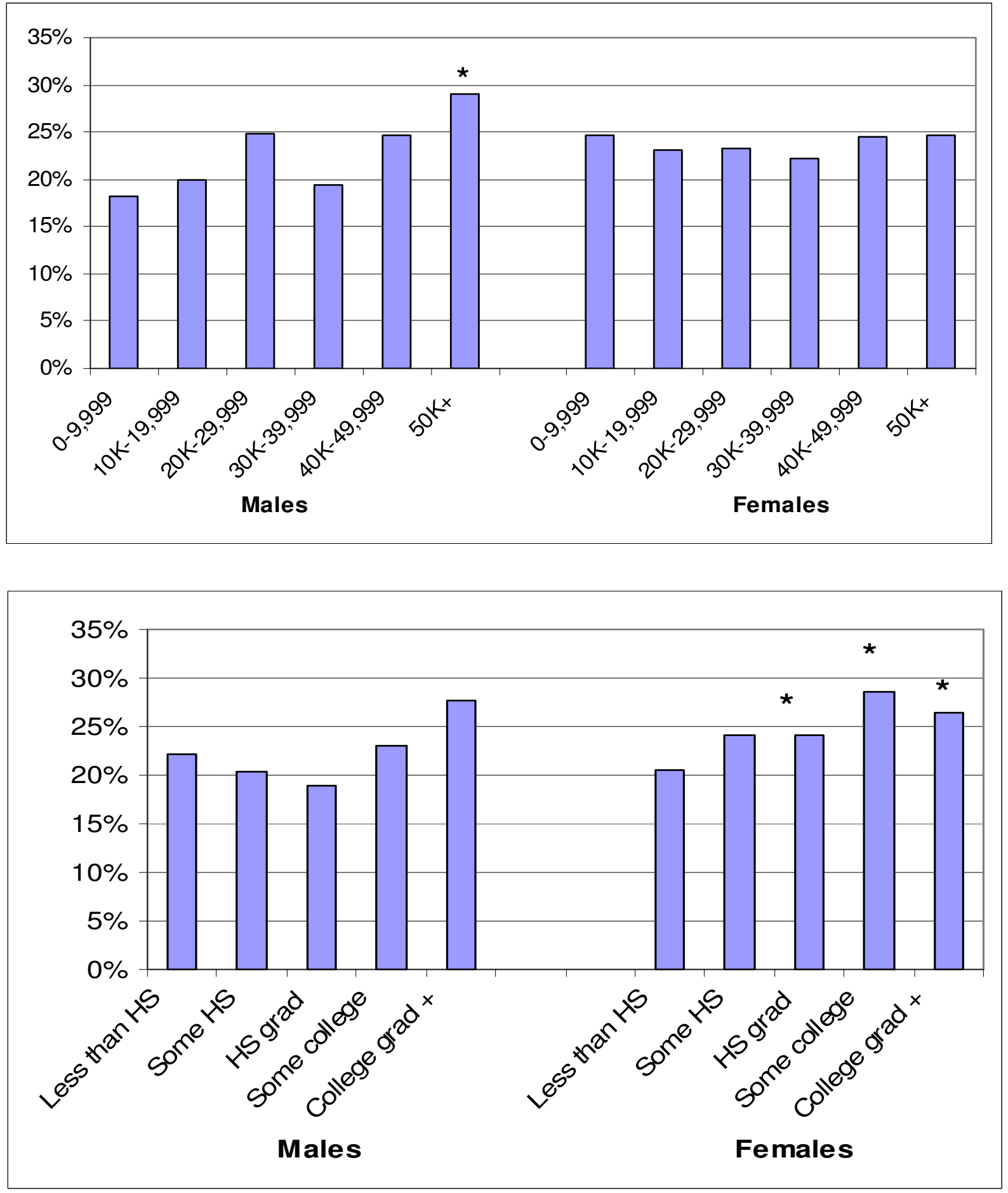

Note: Estimates are adjusted for the age, race, marital status and severity of disability.

* Significantly different from lowest income or education category (p-value $<0.05$ ). 
Figure 7. Use of help by income and education among respondents reporting intrinsic ADL disability

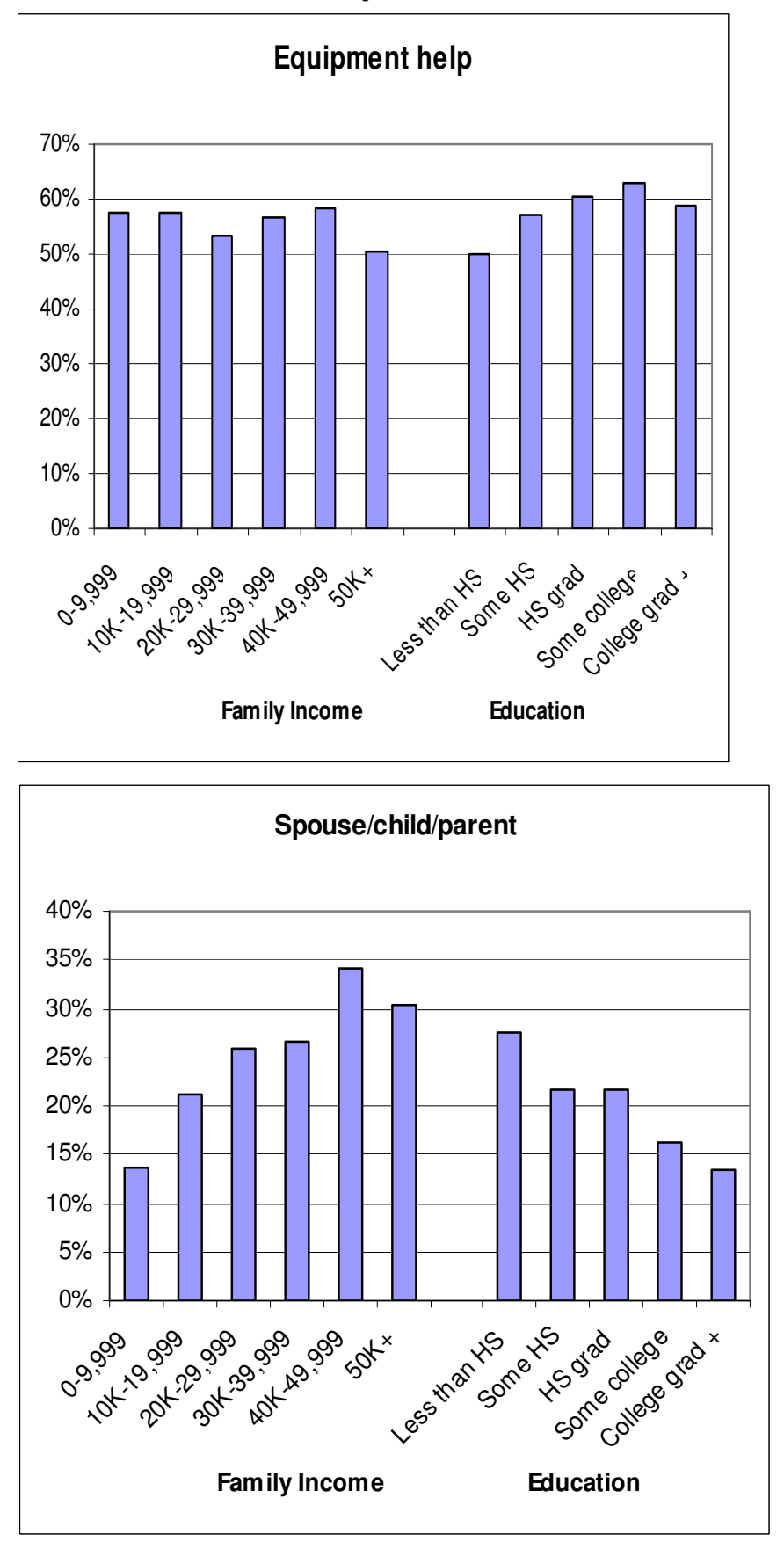



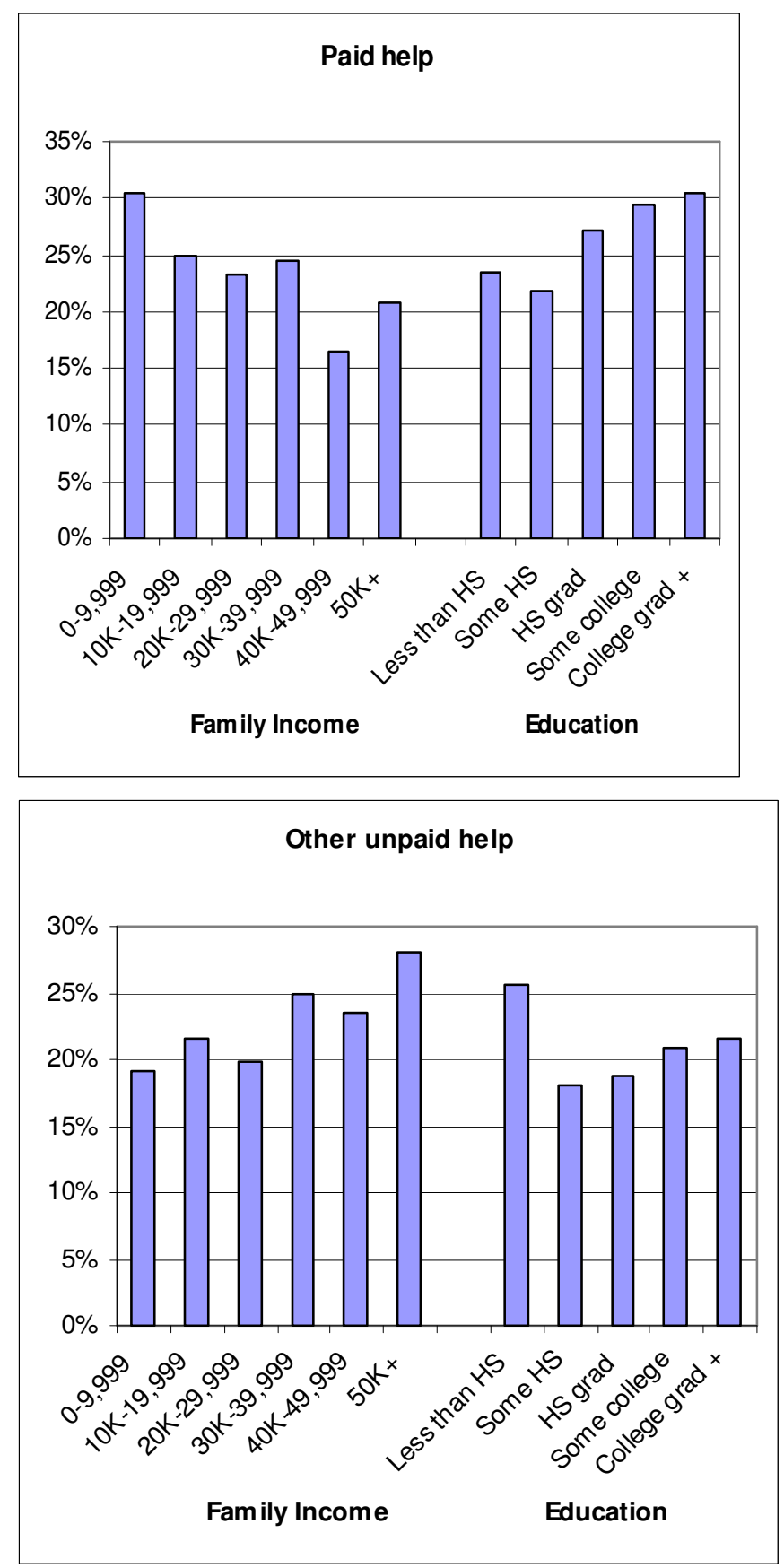
Figure 8. Use of help by income and education among respondents reporting intrinsic IADL disability
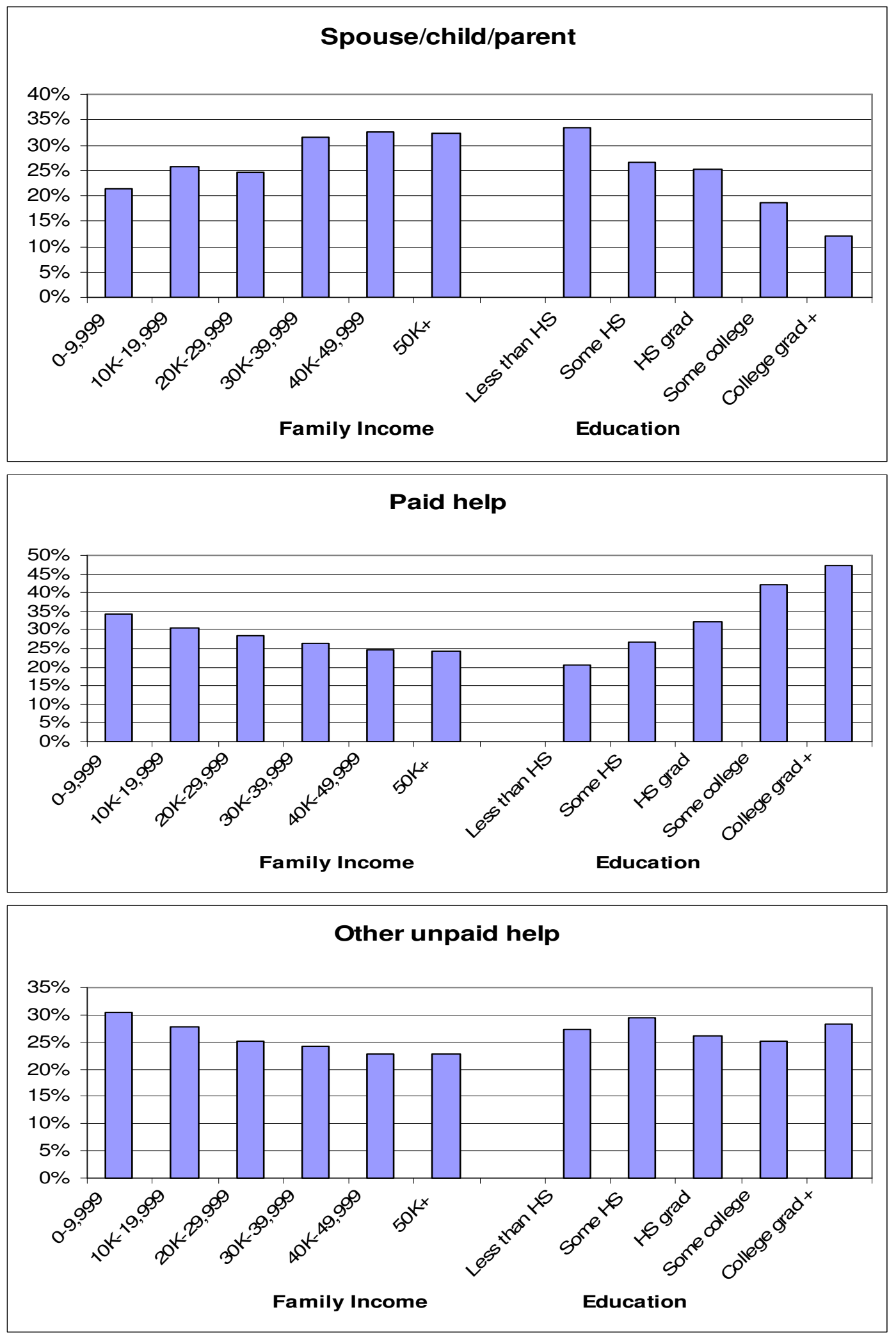
Table 1. Demographic characteristics of 65 and over population from NHIS-D, $1994 \& 1995$

\section{Percent of people}

$(\mathrm{N}=24,791$; weighted $\mathrm{N}=31,245,306)$

Male

41.7

Married

57.0

Div/sep

6.4

Widowed

32.5

Never married

4.0

Unknown marital status

0.1

Black/other

10.5

Age

65-69

31.0

70-74

27.7

$75-79$

19.8

80-84

12.8

85 and over

8.6

Education

Less than high school

21.8

Some HS

15.4

HS grad

34.7

Some college

13.7

College grad or higher

13.3

Unknown educational

1.1

attainment

\begin{tabular}{lc} 
Annual Family Income & \\
$0-9,999$ & 18.3 \\
$10 \mathrm{~K}-19,999$ & 30.8 \\
$20 \mathrm{~K}-29,999$ & 21.3 \\
$30 \mathrm{~K}-39,999$ & 11.6 \\
$40 \mathrm{~K}-49,999$ & 6.5 \\
$50 \mathrm{k}+$ & 11.5 \\
\hline
\end{tabular}


Table 2. Intrinsic and residual disability in the population and ability to cope among the intrinsically disabled, by type of ADL and IADL $(\mathrm{N}=\mathbf{2 4 , 7 9 1 )}$

\begin{tabular}{lccc}
\multicolumn{2}{c}{$\begin{array}{c}\text { \% Reporting } \\
\text { intrinsic } \\
\text { disability }\end{array}$} & $\begin{array}{l}\text { \% Reporting } \\
\text { residual disability }\end{array}$ & $\begin{array}{l}\text { \% of respondents with } \\
\text { instrinsic disability } \\
\text { who cope effectively }\end{array}$ \\
\hline Activities of Daily Living (any) & & & \\
Bathing & 9.5 & 6.4 & 32.3 \\
Getting Around Inside & 7.7 & 4.7 & 39.1 \\
Dressing & 4.4 & 3.2 & 26.6 \\
Transferring & 4.4 & 2.9 & 33.5 \\
Toileting & 4.1 & 3.1 & 25.4 \\
Eating & 3.7 & 2.3 & 36.9 \\
& 1.4 & 0.9 & 37.8 \\
Instrumental Activities of Daily Living & 22.7 & & \\
(any) & & 17.0 & 25.3 \\
Heavy Housework & 21.6 & 15.7 & 27.0 \\
Shopping & 9.8 & 6.7 & 31.9 \\
Light Housework & 7.3 & 5.4 & 26.1 \\
Preparing Meals & 5.9 & 4.1 & 31.3 \\
Managing Money & 4.8 & 3.0 & 36.9 \\
Using the Telephone & 2.5 & 1.7 & 32.1 \\
\hline
\end{tabular}


Table 3. Logistic regression models for intrinsic disability

\begin{tabular}{|c|c|c|c|c|c|c|}
\hline \multirow[b]{2}{*}{ Independent Variable } & \multicolumn{2}{|c|}{ Any Disability } & \multicolumn{2}{|c|}{ Any ADL disability } & \multicolumn{2}{|c|}{ Any IADL disability } \\
\hline & $\begin{array}{l}\text { Coefficient } \\
\text { (SE) }\end{array}$ & $\begin{array}{c}\text { Adjusted } \\
\text { percent }\end{array}$ & $\begin{array}{l}\text { Coefficient } \\
\text { (SE) }\end{array}$ & $\begin{array}{c}\text { Adjusted } \\
\text { percent }\end{array}$ & $\begin{array}{l}\text { Coefficient } \\
\text { (SE) }\end{array}$ & $\begin{array}{c}\text { Adjusted } \\
\text { percent }\end{array}$ \\
\hline \multicolumn{7}{|l|}{ Income } \\
\hline$\$ 0-\$ 9,999$ & - & 28.4 & - & 10.3 & - & 26.6 \\
\hline$\$ 10 \mathrm{~K}-\$ 19,000$ & $-0.24(0.05)^{*}$ & 24.2 & $-0.20(0.06)^{*}$ & 8.7 & $-0.21(0.05)^{*}$ & 22.9 \\
\hline$\$ 20 \mathrm{~K}-\$ 29,999$ & $-0.29(0.06)^{*}$ & 23.4 & $-0.11(0.08)$ & 9.4 & $-0.25(0.06)^{*}$ & 22.3 \\
\hline$\$ 30 \mathrm{~K}-\$ 39,999$ & $-0.32(0.07)^{*}$ & 22.9 & $-0.10(0.10)$ & 9.4 & $-0.29(0.08)^{*}$ & 21.7 \\
\hline$\$ 40 \mathrm{~K}-\$ 49,999$ & $-0.18(0.09)^{*}$ & 25.2 & $-0.05(0.11)$ & 9.9 & $-0.16(0.09)$ & 23.8 \\
\hline$\$ 50 \mathrm{~K}+$ & $-0.43(0.08)^{*}$ & 21.1 & $-0.14(0.11)$ & 9.1 & $-0.41(0.08)^{*}$ & 19.8 \\
\hline \multicolumn{7}{|l|}{ Education } \\
\hline Less than high school & - & 27.9 & - & 11.3 & - & 26.3 \\
\hline Some HS & $-0.08(0.05)$ & 26.5 & $-0.07(0.07)$ & 10.7 & $-0.07(0.05)$ & 25.1 \\
\hline HS graduate & $-0.24(0.05)^{*}$ & 23.7 & $-0.30(0.06)^{*}$ & 8.8 & $-0.24(0.05)^{*}$ & 22.2 \\
\hline Some college & $-0.40(0.06)^{*}$ & 21.1 & $-0.45(0.09)^{*}$ & 7.7 & $-0.39(0.06)^{*}$ & 20.0 \\
\hline College grad or higher & $-0.38(0.07)^{*}$ & 21.4 & $-0.62(0.09)^{*}$ & 6.6 & $-0.34(0.07)^{*}$ & 20.7 \\
\hline Male & $-0.33(0.07)^{*}$ & & $0.01(0.12)$ & & $-0.38(0.07)^{*}$ & \\
\hline Age $70-74$ & $0.18(0.06)^{*}$ & & $0.43(0.10)^{*}$ & & $0.15(0.06)^{*}$ & \\
\hline Age $75-79$ & $0.55(0.07)^{*}$ & & $0.73(0.10)^{*}$ & & $0.51(0.07)^{*}$ & \\
\hline Age $80-84$ & $0.98(0.07)^{*}$ & & $1.42(0.11)^{*}$ & & $0.93(0.07)^{*}$ & \\
\hline Age $85+$ & $1.57(0.08)^{*}$ & & $1.94(0.11)^{*}$ & & $1.52(0.08)^{*}$ & \\
\hline \multicolumn{7}{|l|}{$A g e^{*} \operatorname{sex}$} \\
\hline $70-74 *$ male & $0.05(0.10)$ & & $0.28(0.17)$ & & $0.06(0.10)$ & \\
\hline $75-79 *$ male & $-0.02(0.11)$ & & $-0.14(0.17)$ & & $-0.06(0.11)$ & \\
\hline $80-84 *$ male & $0.11(0.10)$ & & $0.24(0.17)$ & & $0.09(0.10)$ & \\
\hline 85 plus*male & $0.01(0.12)$ & & $0.23(0.17)$ & & $0.02(0.12)$ & \\
\hline Widowed & $0.32(0.05)^{*}$ & & $0.29(0.07)^{*}$ & & $0.33(0.05)^{*}$ & \\
\hline Divorced/separated/single & $0.26(0.18)^{*}$ & & $0.34(0.10)^{*}$ & & $0.24(0.08)^{*}$ & \\
\hline \multicolumn{7}{|l|}{ Marital status*sex } \\
\hline Widowed*male & $0.02(0.09)$ & & $-0.07(0.13)$ & & $0.05(0.09)$ & \\
\hline $\begin{array}{l}\text { Divorced/separated/ } \\
\text { Single*male }\end{array}$ & $0.02(0.11)$ & & $-0.11(0.16)$ & & $0.13(0.11)$ & \\
\hline Black/other race & $0.11(0.06)$ & & $0.18(0.08)^{*}$ & & $0.12(0.06)^{*}$ & \\
\hline $\mathrm{N}$ & 24,476 & & 24,476 & & 24,476 & \\
\hline
\end{tabular}

The definition of intrinsic ADL disability includes difficulty alone or without help or equipment; the definition for intrinsic IADL disability includes only difficulty alone or without help.

Individuals missing values for educational attainment $(n=295)$ and/or marital status $(n=25)$ were dropped from regression analyses

$* \mathrm{p}<0.05$ 
Table 4. Logistic Regression Models for Residual Disability

\begin{tabular}{|c|c|c|c|c|c|c|}
\hline & \multicolumn{2}{|c|}{ Any Disability } & \multicolumn{2}{|c|}{ Any ADL disability } & \multicolumn{2}{|c|}{ Any IADL disability } \\
\hline & $\begin{array}{l}\text { Coefficient } \\
\text { (SE) }\end{array}$ & $\begin{array}{c}\text { Adjusted } \\
\text { percent }\end{array}$ & $\begin{array}{l}\text { Coefficient } \\
\text { (SE) }\end{array}$ & $\begin{array}{c}\text { Adjusted } \\
\text { percent }\end{array}$ & $\begin{array}{l}\text { Coefficient } \\
\text { (SE) }\end{array}$ & $\begin{array}{c}\text { Adjusted } \\
\text { percent }\end{array}$ \\
\hline \multicolumn{7}{|l|}{ Income } \\
\hline$\$ 0-\$ 9,999$ & - & 21.5 & - & 7.1 & - & 19.8 \\
\hline$\$ 10 \mathrm{~K}-\$ 19,000$ & $-0.19(0.05)^{*}$ & 18.7 & $-0.20(0.07)^{*}$ & 5.9 & $-0.17(0.06)^{*}$ & 17.4 \\
\hline$\$ 20 \mathrm{~K}-\$ 29,999$ & $-0.26(0.06)^{*}$ & 17.8 & $-0.15(0.09)$ & 6.2 & $-0.25(0.07)^{*}$ & 16.3 \\
\hline$\$ 30 \mathrm{~K}-\$ 39,999$ & $-0.24(0.08)^{*}$ & 18.0 & $-0.07(0.12)$ & 6.6 & $-0.23(0.09)^{*}$ & 16.5 \\
\hline$\$ 40 \mathrm{~K}-\$ 49,999$ & $-0.16(0.09)$ & 19.2 & $0.03(0.13)$ & 7.3 & $-0.15(0.10)$ & 17.6 \\
\hline$\$ 50 \mathrm{~K}+$ & $-0.42(0.09)^{*}$ & 15.7 & $-0.27(0.15)$ & 5.5 & $-0.42(0.09)^{*}$ & 14.2 \\
\hline \multicolumn{7}{|l|}{ Education } \\
\hline Less than high school & - & 22.1 & - & 8.3 & - & 20.0 \\
\hline Some HS & $-0.11(0.05)^{*}$ & 20.4 & $-0.18(0.08)^{*}$ & 7.1 & $-0.09(0.05)$ & 18.7 \\
\hline HS graduate & $-0.26(0.05)^{*}$ & 18.2 & $-0.41(0.07)^{*}$ & 5.8 & $-0.22(0.05)^{*}$ & 16.9 \\
\hline Some college & $-0.48(0.06)^{*}$ & 15.4 & $-0.63(0.11)^{*}$ & 4.7 & $-0.43(0.06)^{*}$ & 14.3 \\
\hline College grad or higher & $-0.49(0.07)^{*}$ & 15.3 & $-0.67(0.11)^{*}$ & 4.5 & $-0.42(0.07)^{*}$ & 14.4 \\
\hline Male & $-0.31(0.08)^{*}$ & & $0.04(0.13)$ & & $-0.33(0.05)^{*}$ & \\
\hline Age $70-74$ & $0.12(0.07)$ & & $0.45(0.11)^{*}$ & & $0.10(0.07)$ & \\
\hline Age 75-79 & $0.49(0.07)^{*}$ & & $0.72(0.12)^{*}$ & & $0.48(0.07)^{*}$ & \\
\hline Age $80-84$ & $0.89(0.07)^{*}$ & & $1.37(0.12)^{*}$ & & $0.83(0.08) *$ & \\
\hline Age $85+$ & $1.40(0.09)^{*}$ & & $1.81(0.13)^{*}$ & & $1.33(0.09)^{*}$ & \\
\hline \multicolumn{7}{|l|}{ Age*sex } \\
\hline 70-74*male & $0.10(0.11)$ & & $-0.42(0.20)^{*}$ & & $0.14(0.11)$ & \\
\hline $75-79 *$ male & $0.01(0.11)$ & & $0.06(0.19)$ & & $-0.06(0.12)$ & \\
\hline $80-84 *$ male & $0.11(0.12)$ & & $-0.22(0.18)$ & & $0.11(0.12)$ & \\
\hline 85 plus*male & $0.16(0.13)$ & & $-0.26(0.20)$ & & $0.15(0.13)$ & \\
\hline Widowed & $0.27(0.06)^{*}$ & & $0.12(0.09)$ & & $0.29(0.06)^{*}$ & \\
\hline Divorced/separated/single & $0.32(0.07)^{*}$ & & $0.30(0.11)^{*}$ & & $0.31(0.08)^{*}$ & \\
\hline \multicolumn{7}{|l|}{ Marital status ${ }^{*}$ sex } \\
\hline Widowed*male & $0.01(0.10)$ & & $-0.04(0.16)$ & & $0.01(0.10)$ & \\
\hline $\begin{array}{l}\text { Divorced/separate/ } \\
\text { single*male }\end{array}$ & $-0.04(0.12)$ & & $-0.20(0.19)$ & & $0.03(0.12)$ & \\
\hline Black/other race & $0.10(0.07)$ & & $0.16(0.09)$ & & $0.12(0.07)$ & \\
\hline $\mathrm{N}$ & 24,476 & & 24,476 & & 24,476 & \\
\hline
\end{tabular}

The definition of intrinsic ADL disability includes difficulty alone or without help or equipment; the definition for intrinsic IADL disability includes only difficulty alone or without help.

Individuals missing values for educational attainment $(n=295)$ and/or marital status $(n=25)$ were dropped from regression analyses

$* \mathrm{p}<0.05$ 
Table 5. Logistic Regression Models for Ability to Cope

\begin{tabular}{|c|c|c|c|c|c|c|}
\hline & \multicolumn{2}{|c|}{ Any Disability } & \multicolumn{2}{|c|}{ Any ADL disability } & \multicolumn{2}{|c|}{ Any IADL disability } \\
\hline & $\begin{array}{l}\text { Coefficient } \\
\text { (SE) }\end{array}$ & $\begin{array}{c}\text { Adjusted } \\
\text { percent }\end{array}$ & $\begin{array}{l}\text { Coefficient } \\
\text { (SE) }\end{array}$ & $\begin{array}{c}\text { Adjusted } \\
\text { percent }\end{array}$ & $\begin{array}{l}\text { Coefficient } \\
\text { (SE) }\end{array}$ & $\begin{array}{c}\text { Adjusted } \\
\text { percent }\end{array}$ \\
\hline \multicolumn{7}{|l|}{ Income } \\
\hline$\$ 0-\$ 9,999$ & - & 23.2 & - & 30.3 & - & 25.0 \\
\hline$\$ 10 \mathrm{~K}-\$ 19,000$ & $-0.06(0.10)$ & 22.3 & $0.10(0.14)$ & 32.1 & $-0.05(0.10)$ & 24.0 \\
\hline$\$ 20 \mathrm{~K}-\$ 29,999$ & $0.04(0.11)$ & 23.9 & $0.16(0.16)$ & 33.4 & $0.10(0.11)$ & 26.8 \\
\hline$\$ 30 \mathrm{~K}-\$ 39,999$ & $-0.12(0.15)$ & 21.2 & $0.01(0.19)$ & 30.5 & $-0.06(0.16)$ & 23.9 \\
\hline$\$ 40 \mathrm{~K}-\$ 49,999$ & $0.06(0.18)$ & 24.2 & $0.03(0.26)$ & 30.8 & $0.04(0.16)$ & 25.8 \\
\hline$\$ 50 \mathrm{~K}+$ & $0.16(0.16)$ & 26.0 & $0.43(0.26)$ & 38.7 & $0.17(0.16)$ & 28.2 \\
\hline \multicolumn{7}{|l|}{ Education } \\
\hline Less than high school & - & 20.9 & - & 27.3 & - & 24.4 \\
\hline Some HS & $0.13(0.10)$ & 23.0 & $0.31(0.14)^{*}$ & 33.1 & $0.06(0.09)$ & 25.5 \\
\hline HS graduate & $0.11(0.09)$ & 22.6 & $0.44(0.13)^{*}$ & 35.6 & $-0.06(0.08)$ & 23.5 \\
\hline Some college & $0.35(0.12)^{*}$ & 27.0 & $0.54(0.21)^{*}$ & 37.5 & $0.20(0.12)$ & 28.2 \\
\hline College grad or higher & $0.38(0.12)^{*}$ & 27.6 & $0.19(0.21)$ & 30.8 & $0.26(0.12)^{*}$ & 29.3 \\
\hline Male & $0.01(0.15)$ & & $-0.12(0.27)$ & & $-0.11(0.15)$ & \\
\hline Age $70-74$ & $0.22(0.11)$ & & $-0.14(0.20)$ & & $0.17(0.12)$ & \\
\hline Age $75-79$ & $0.11(0.13)$ & & $-0.07(0.21)$ & & $0.04(0.13)$ & \\
\hline Age $80-84$ & $0.14(0.13)$ & & $0.03(0.19)$ & & $0.18(0.14)$ & \\
\hline Age $85+$ & $0.09(0.14)$ & & $0.13(0.19)$ & & $0.18(0.14)$ & \\
\hline \multicolumn{7}{|l|}{ Age*sex } \\
\hline $70-74 *$ male & $-0.25(0.19)$ & & $0.52(0.32)$ & & $-0.29(0.20)$ & \\
\hline $75-79 *$ male & $0.04(0.21)$ & & $0.31(0.33)$ & & $0.07(0.21)$ & \\
\hline $80-84 *$ male & $0.05(0.21)$ & & $-0.04(0.33)$ & & $0.00(0.22)$ & \\
\hline 85 plus*male & $-0.32(0.22)$ & & $0.30(0.35)$ & & $-0.24(0.23)$ & \\
\hline Widowed & $0.07(0.10)$ & & $0.34(0.16)^{*}$ & & $0.04(0.10)$ & \\
\hline Divorced/separated/single & $-0.20(0.14)$ & & $0.01(0.21)$ & & $-0.19(0.14)$ & \\
\hline \multicolumn{7}{|l|}{ Marital status ${ }^{*}$ sex } \\
\hline Widowed*male & $-0.01(0.17)$ & & $-0.15(0.26)$ & & $0.17(0.17)$ & \\
\hline Divorced/sep/single*male & $0.13(0.23)$ & & $0.19(0.39)$ & & $0.31(0.23)$ & \\
\hline Black/other race & $0.08(0.11)$ & & $0.07(0.17)$ & & $0.03(0.11)$ & \\
\hline \multicolumn{7}{|l|}{ Limitations } \\
\hline IADL only & Ref & & NA & & NA & \\
\hline 1-2 ADLs & $-0.31(0.08)^{*}$ & & Ref & & NA & \\
\hline 3 or more ADLs & $-1.61(0.16)^{*}$ & & $-1.72(0.14)^{*}$ & & NA & \\
\hline 3 or more IADLs & NA & & NA & & $-0.86(0.08)^{*}$ & \\
\hline $\mathrm{N}$ & 5868 & & 2266 & & 5557 & \\
\hline $\begin{array}{l}\text { The definition of intrinsic } A \\
\text { definition for intrinsic IAD } \\
\text { These models include only } \\
* \mathrm{p}<0.05\end{array}$ & $\begin{array}{l}\text { L disability } \\
\text { disability inc } \\
\text { spondents } \mathrm{w}\end{array}$ & $\begin{array}{l}\text { ludes di } \\
\text { es only } \\
\text { reportec }\end{array}$ & $\begin{array}{l}\text { culty alone or } \\
\text { fficulty alone } \\
\text { trinsic disabi }\end{array}$ & $\begin{array}{l}\text { out h } \\
\text { thout }\end{array}$ & $\begin{array}{l}\text { or equipment; } \\
\text { p. }\end{array}$ & \\
\hline
\end{tabular}


Table 6. Logistic regression models for ability to dope, including functional limitations

\begin{tabular}{|c|c|c|c|c|c|c|}
\hline & \multicolumn{2}{|c|}{ Any Disability } & \multicolumn{2}{|c|}{ ADL Only } & \multicolumn{2}{|c|}{ IADL Only } \\
\hline & $\begin{array}{c}\text { Coefficient } \\
(\mathrm{SE})\end{array}$ & $\begin{array}{c}\text { Adjusted } \\
\text { Percent }\end{array}$ & $\begin{array}{c}\text { Coefficient } \\
(\mathrm{SE})\end{array}$ & $\begin{array}{c}\text { Adjusted } \\
\text { Percent }\end{array}$ & $\begin{array}{c}\text { Coefficient } \\
(\mathrm{SE})\end{array}$ & $\begin{array}{l}\text { Adjusted } \\
\text { Percent }\end{array}$ \\
\hline \multicolumn{7}{|l|}{ Income } \\
\hline$\$ 0-\$ 9,999$ & - & 23.8 & - & 30.8 & - & 25.4 \\
\hline $\begin{array}{l}\$ 10 \mathrm{~K}- \\
\$ 19,000\end{array}$ & $-0.09(0.10)$ & 22.2 & $0.05(0.14)$ & 31.7 & $-0.07(0.10)$ & 24.0 \\
\hline $\begin{array}{l}\$ 20 \mathrm{~K}- \\
\$ 29,999\end{array}$ & $-0.02(0.11)$ & 23.5 & $0.14(0.16)$ & 33.4 & $0.06(0.11)$ & 26.5 \\
\hline $\begin{array}{l}\$ 30 \mathrm{~K}- \\
\$ 39,999\end{array}$ & $-0.17(0.16)$ & 21.1 & $0.01(0.19)$ & 30.9 & $-0.08(0.16)$ & 23.9 \\
\hline $\begin{array}{l}\$ 40 \mathrm{~K}- \\
\$ 49,999\end{array}$ & $0.02(0.17)$ & 24.2 & $-0.03(0.26)$ & 30.3 & $0.03(0.16)$ & 25.9 \\
\hline$\$ 50 \mathrm{~K}+$ & $0.08(0.17)$ & 25.2 & $0.42(0.27)$ & 38.7 & $0.13(0.16)$ & 27.7 \\
\hline \multicolumn{7}{|l|}{ Education } \\
\hline $\begin{array}{l}\text { Less than } \\
\text { high school }\end{array}$ & - & 21.6 & - & 28.0 & - & 24.8 \\
\hline Some HS & $0.10(0.10)$ & 23.2 & $0.27(0.14)$ & 33.0 & $0.04(0.10)$ & 25.6 \\
\hline HS graduate & $0.05(0.09)$ & 22.4 & $\begin{array}{c}0.39 \\
(0.13)^{*}\end{array}$ & 35.3 & $-0.08(0.08)$ & 23.4 \\
\hline Some college & $\begin{array}{c}0.27 \\
(0.12)^{*}\end{array}$ & 26.2 & $\begin{array}{c}0.45 \\
(0.20)^{*}\end{array}$ & 36.4 & $0.16(0.12)$ & 27.8 \\
\hline $\begin{array}{l}\text { College grad } \\
\text { or higher }\end{array}$ & $\begin{array}{c}0.29 \\
(0.13)^{*}\end{array}$ & 26.6 & $0.14(0.21)$ & 30.5 & $0.20(0.12)$ & 28.6 \\
\hline $\mathrm{N}$ & 5868 & & 2266 & & 5557 & \\
\hline \multicolumn{7}{|c|}{$\begin{array}{l}\text { The definition of intrinsic ADL disability includes difficulty alone or without help or equipment; } \\
\text { the definition for intrinsic IADL disability includes only difficulty alone or without help. } \\
\text { These models include only respondents who reported intrinsic disability } \\
\text { Models all control for race, age*sex, sex*marital status, functional limitations, and the number of } \\
\text { reported IADLs and ADLs. For the any disability model, categorical variables for included } 1-2 \\
\text { ADLs and } 3 \text { or more ADLs were included (IADL only was reference category). For the ADL and } \\
\text { IADL only models, dichotomous variables for } 3 \text { or more ADLs or } 3 \text { or more IADLs were } \\
\text { included in the models, respectively. } \\
* \text { p }<0.05\end{array}$} \\
\hline
\end{tabular}


Table 7. Use of equipment and personal help among respondents with intrinsic disability, by ADL and IADL category

\begin{tabular}{lccc}
\hline & Equipment & $\begin{array}{c}\text { Any personal } \\
\text { help }\end{array}$ & $\begin{array}{c}\text { Equipment and/or } \\
\text { personal help }\end{array}$ \\
\hline $\begin{array}{l}\text { Activities of Daily Living (any) } \\
(n=2266)\end{array}$ & 56.1 & 64.4 & 90.3 \\
$\begin{array}{l}\text { Bathing } \\
\text { (n=1835) }\end{array}$ & 40.8 & 70.8 & 90.9 \\
$\begin{array}{l}\text { Getting Around Inside } \\
\text { (n=1025) }\end{array}$ & 61.6 & 49.0 & 87.0 \\
$\begin{array}{l}\text { Dressing } \\
\text { (n=1066) }\end{array}$ & 5.0 & 84.9 & 86.4 \\
$\begin{array}{l}\text { Transferring } \\
\text { (n=995) }\end{array}$ & 28.3 & 60.9 & 74.6 \\
$\begin{array}{l}\text { Toileting } \\
\text { (n=881) }\end{array}$ & 60.9 & 54.7 & 91.0 \\
$\begin{array}{l}\text { Eating } \\
\text { (n=336) }\end{array}$ & 9.5 & 81.1 & 84.6 \\
$\begin{array}{l}\text { Instrumental Activities } \text { of Daily } \\
\begin{array}{l}\text { Living (any) } \\
\text { Heavy Housework } \\
\text { (n=5274) }\end{array}\end{array}$ & N/A & 88.4 & 88.4 \\
$\begin{array}{l}\text { Shopping } \\
\text { (n=2399) }\end{array}$ & N/A & 86.6 & 86.6 \\
$\begin{array}{l}\text { Light Housework } \\
\text { (n=1765) }\end{array}$ & N/A & 91.3 & 91.3 \\
$\begin{array}{l}\text { Preparing Meals } \\
\text { (n=1432) }\end{array}$ & N/A & 87.1 & 87.1 \\
$\begin{array}{l}\text { Managing Money } \\
\text { (n=1155) }\end{array}$ & N/A & 86.9 & 86.9 \\
$\begin{array}{l}\text { Using the Telephone } \\
\text { (n=596) }\end{array}$ & 92.5 & 92.5 \\
\hline
\end{tabular}


Table 8. Logistic regression models for use of equipment and help for "any ADL", conditioned on reported intrinsic ADL disability

\begin{tabular}{|c|c|c|c|c|c|c|}
\hline & $\begin{array}{c}\text { Model 1: } \\
\text { Any } \\
\text { equipment }\end{array}$ & $\begin{array}{l}\text { Model 2: } \\
\text { Any help } \\
\text { from spouse, } \\
\text { child, or } \\
\text { parent }\end{array}$ & $\begin{array}{l}\text { Model 3: } \\
\text { Any paid } \\
\text { help }\end{array}$ & $\begin{array}{c}\text { Model 4: } \\
\text { Any other } \\
\text { unpaid help }\end{array}$ & $\begin{array}{c}\text { Model 5: } \\
\text { Any type } \\
\text { of personal } \\
\text { help }\end{array}$ & $\begin{array}{l}\text { Model 6: } \\
\text { Any type } \\
\text { of personal } \\
\text { help and/or } \\
\text { equipment }\end{array}$ \\
\hline \multicolumn{7}{|l|}{ Income } \\
\hline$\$ 0-\$ 9,999$ & - & - & - & - & - & - \\
\hline$\$ 10 \mathrm{~K}-\$ 19,000$ & $\begin{array}{c}0.01 \\
(0.12)\end{array}$ & $\begin{array}{c}0.57 \\
(0.17)^{*}\end{array}$ & $\begin{array}{l}-0.30 \\
(0.16)\end{array}$ & $\begin{array}{c}0.17 \\
(0.16)\end{array}$ & $\begin{array}{c}0.13 \\
(0.15)\end{array}$ & $\begin{array}{c}0.15 \\
(0.21)\end{array}$ \\
\hline$\$ 20 \mathrm{~K}-\$ 29,999$ & $\begin{array}{l}-0.19 \\
(0.15)\end{array}$ & $\begin{array}{c}0.85 \\
(0.19)^{*}\end{array}$ & $\begin{array}{l}-0.40 \\
(0.17)^{*}\end{array}$ & $\begin{array}{c}0.06 \\
(0.19)\end{array}$ & $\begin{array}{c}0.17 \\
(0.15)\end{array}$ & $\begin{array}{c}0.14 \\
(0.25)\end{array}$ \\
\hline$\$ 30 \mathrm{~K}-\$ 39,999$ & $\begin{array}{l}-0.04 \\
(0.18)\end{array}$ & $\begin{array}{c}0.90 \\
(0.23)^{*}\end{array}$ & $\begin{array}{l}-0.32 \\
(0.20)\end{array}$ & $\begin{array}{c}0.38 \\
(0.20)\end{array}$ & $\begin{array}{c}0.39 \\
(0.21)\end{array}$ & $\begin{array}{c}0.44 \\
(0.35)\end{array}$ \\
\hline$\$ 40 \mathrm{~K}-\$ 49,999$ & $\begin{array}{c}0.03 \\
(0.23)\end{array}$ & $\begin{array}{c}1.28 \\
(0.28)^{*}\end{array}$ & $\begin{array}{c}-0.87 \\
(0.28)^{*}\end{array}$ & $\begin{array}{c}0.30 \\
(0.25)\end{array}$ & $\begin{array}{c}0.63 \\
(0.25)^{*}\end{array}$ & $\begin{array}{c}0.40 \\
(0.40)\end{array}$ \\
\hline$\$ 50 \mathrm{~K}+$ & $\begin{array}{l}-0.32 \\
(0.21)\end{array}$ & $\begin{array}{c}1.10 \\
(0.26)^{*}\end{array}$ & $\begin{array}{c}-0.55 \\
(0.23)^{*}\end{array}$ & $\begin{array}{c}0.56 \\
(0.23)^{*}\end{array}$ & $\begin{array}{c}0.85 \\
(0.22)^{*}\end{array}$ & $\begin{array}{c}0.14 \\
(0.30)\end{array}$ \\
\hline \multicolumn{7}{|l|}{ Education } \\
\hline $\begin{array}{l}\text { Less than HS } \\
\text { Some HS }\end{array}$ & $\begin{array}{c}- \\
0.35 \\
(0.13)^{*}\end{array}$ & $\begin{array}{c}- \\
-0.36 \\
(0.19)\end{array}$ & $\begin{array}{c}- \\
-0.10 \\
(0.15)\end{array}$ & $\begin{array}{c}- \\
-0.49 \\
(0.16)^{*}\end{array}$ & $\begin{array}{c}- \\
-0.49 \\
(0.16)^{*}\end{array}$ & $\begin{array}{c}- \\
-0.09 \\
(0.21)\end{array}$ \\
\hline HS graduate & $\begin{array}{c}0.49 \\
(0.12)^{*}\end{array}$ & $\begin{array}{c}-0.36 \\
(0.15)^{*}\end{array}$ & $\begin{array}{c}0.22 \\
(0.15)\end{array}$ & $\begin{array}{l}-0.45 \\
(0.15)^{*}\end{array}$ & $\begin{array}{l}-0.26 \\
(0.14)\end{array}$ & $\begin{array}{c}0.06 \\
(0.21)\end{array}$ \\
\hline Some college & $\begin{array}{c}0.61 \\
(0.17)^{*}\end{array}$ & $\begin{array}{c}-0.74 \\
(0.22)^{*}\end{array}$ & $\begin{array}{c}0.34 \\
(0.20)\end{array}$ & $\begin{array}{l}-0.30 \\
(0.20)\end{array}$ & $\begin{array}{c}-0.49 \\
(0.19)^{*}\end{array}$ & $\begin{array}{c}0.22 \\
(0.32)\end{array}$ \\
\hline College grad + & $\begin{array}{c}0.42 \\
(0.17)^{*}\end{array}$ & $\begin{array}{c}-0.99 \\
(0.25)^{*}\end{array}$ & $\begin{array}{c}0.40 \\
(0.20)^{*}\end{array}$ & $\begin{array}{l}-0.25 \\
(0.23)\end{array}$ & $\begin{array}{l}-0.65 \\
(0.21)^{*}\end{array}$ & $\begin{array}{l}-0.13 \\
(0.28)\end{array}$ \\
\hline Average use & $56.1 \%$ & $22.1 \%$ & $25.3 \%$ & $21.3 \%$ & $64.4 \%$ & $30.2 \%$ \\
\hline $\mathrm{N}$ & 2266 & 2266 & 2266 & 2266 & 2266 & 2266 \\
\hline $\begin{array}{l}\text { Models control } \\
\text { report difficulty } \\
* \mathrm{p}<0.05\end{array}$ & $\begin{array}{l}\text { ce, age* } \\
3 \text { or mo }\end{array}$ & $\begin{array}{l}\text { ex*marita } \\
\text { Ls }\end{array}$ & s, funct & imitatio & whethe & ondents \\
\hline
\end{tabular}


Table 9. Logistic regression models for use of help for "any IADL", conditioned on reporting intrinsic IADL disability

\begin{tabular}{|c|c|c|c|c|}
\hline & $\begin{array}{c}\text { Model 1: } \\
\text { Any help from } \\
\text { Spouse, child, } \\
\text { or parent }\end{array}$ & $\begin{array}{c}\text { Model 2: } \\
\text { Any paid help }\end{array}$ & $\begin{array}{l}\text { Model 3: } \\
\text { Any unpaid } \\
\text { help }\end{array}$ & $\begin{array}{l}\text { Model 4: } \\
\text { Any help }\end{array}$ \\
\hline \multicolumn{5}{|l|}{ Income } \\
\hline$\$ 0-\$ 9,999$ & - & - & - & - \\
\hline$\$ 10 \mathrm{~K}-\$ 19,000$ & $0.25(0.08)^{*}$ & $-0.19(0.09)^{*}$ & $-0.13(0.09)$ & $-0.10(0.14)$ \\
\hline$\$ 20 \mathrm{~K}-\$ 29,999$ & $0.20(0.10)$ & $-0.29(0.11)^{*}$ & $-0.27(0.11)^{*}$ & $-0.27(0.15)$ \\
\hline$\$ 30 \mathrm{~K}-\$ 39,999$ & $0.55(0.14) *$ & $-0.41(0.14)^{*}$ & $-0.32(0.14)^{*}$ & $-0.11(0.20)$ \\
\hline$\$ 40 \mathrm{~K}-\$ 49,999$ & $0.60(0.16)^{*}$ & $-0.51(0.18)^{*}$ & $-0.34(0.18)$ & $0.21(0.28)$ \\
\hline$\$ 50 \mathrm{~K}+$ & $0.59(0.15)^{*}$ & $-0.52(0.15)^{*}$ & $-0.40(0.14)^{*}$ & $-0.19(0.23)$ \\
\hline \multicolumn{5}{|l|}{ Education } \\
\hline Less than HS & - & - & - & - \\
\hline Some HS & $-0.34(0.10)^{*}$ & $0.36(0.10)^{*}$ & $0.10(0.10)$ & $-0.11(0.13)$ \\
\hline HS graduate & $-0.43(0.08)^{*}$ & $0.63(0.08)^{*}$ & $-0.07(0.09)$ & $-0.19(0.11)$ \\
\hline Some college & $-0.83(0.13)^{*}$ & $1.08(0.11)^{*}$ & $-0.12(0.12)$ & $0.09(0.18)$ \\
\hline College grad + & $-1.35(0.16)^{*}$ & $1.30(0.12)^{*}$ & $0.05(0.13)$ & $-0.05(0.16)$ \\
\hline Average use & 25.49 & 29.90 & 27.31 & 88.44 \\
\hline $\mathrm{N}$ & 5557 & 5557 & 5557 & 5557 \\
\hline \multicolumn{5}{|c|}{$\begin{array}{l}\text { Models all control for race, age*sex, sex*marital status, functional limitations, and } \\
\text { whether respondent reports difficulty with } 3 \text { or more IADLs } \\
* \mathrm{p}<0.05\end{array}$} \\
\hline
\end{tabular}


Table 10. Logistic regression models for ADL coping, including covariates for use of equipment and help

$\begin{array}{lccc}\text { Coefficient (SE) } & \begin{array}{c}\text { Adjusted } \\ \text { percent }\end{array} & \text { Coefficient (SE) } & \text { Adjusted percent }\end{array}$

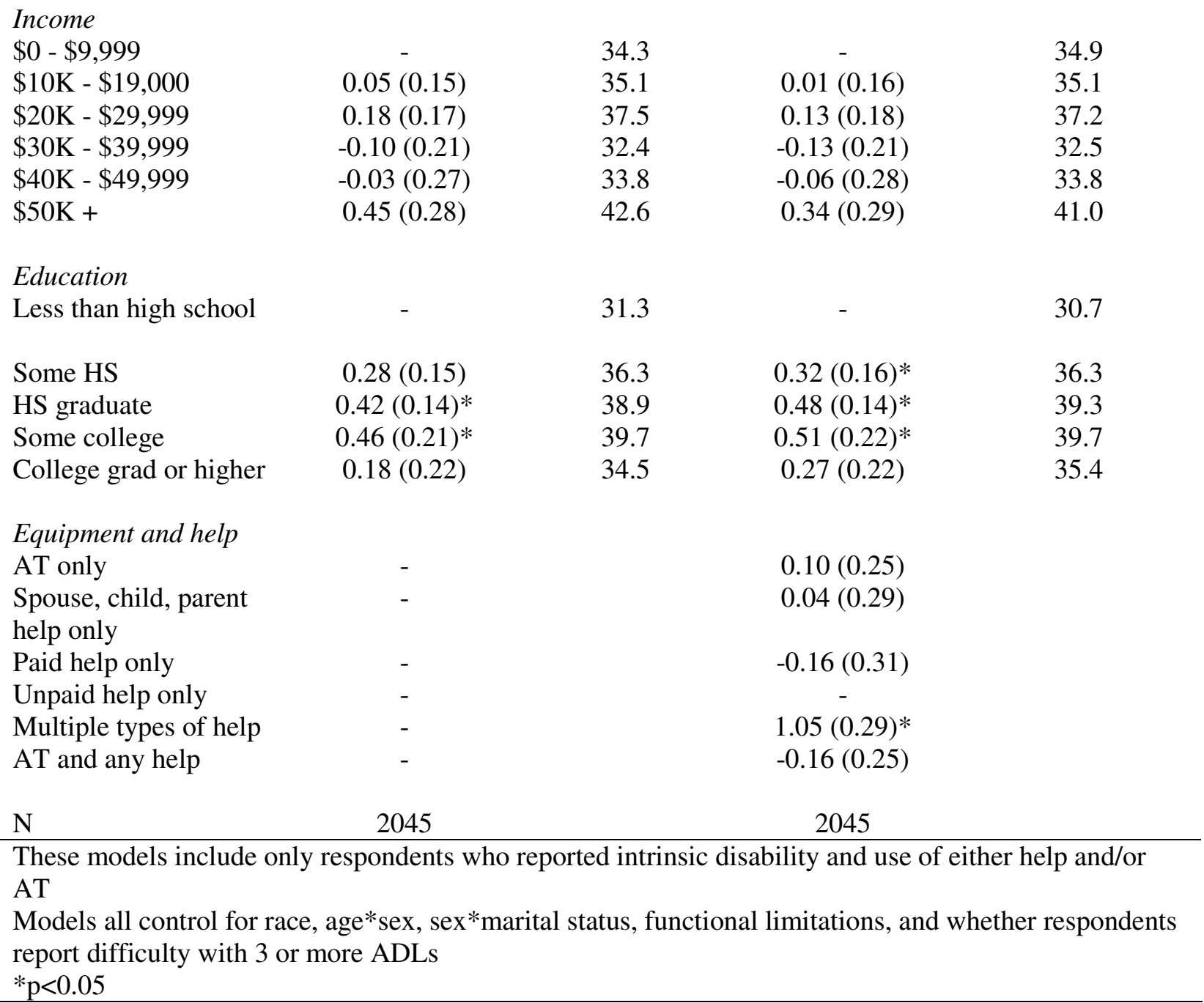


Table 11. Logistic Regression Models for IADL Coping, including covariates for use of equipment and help

\begin{tabular}{cccccc}
\hline $\begin{array}{c}\text { Coefficient } \\
(\mathrm{SE})\end{array}$ & $\begin{array}{c}\text { Adjusted } \\
\text { percent }\end{array}$ & $\begin{array}{c}\text { Coefficient } \\
(\mathrm{SE})\end{array}$ & $\begin{array}{c}\text { Adjusted } \\
\text { percent }\end{array}$ & $\begin{array}{c}\text { Coefficient } \\
(\mathrm{SE})\end{array}$ & $\begin{array}{c}\text { Adjusted } \\
\text { percent }\end{array}$ \\
\hline
\end{tabular}

Income

$\$ 0$ - $\$ 9,999$

$\$ 10 \mathrm{~K}-\$ 19,000$

$-\quad 28.2$

$-0.06(0.10) \quad 27.0$

$-\quad 27.5$

27.9

$0.02(0.11)$

30.8

$0.03(0.11)$

27.5

$\$ 20 \mathrm{~K}-\$ 29,999$

$0.14(0.12) \quad 30.8$

$0.20(0.12)$

$0.19(0.12)$

28.0

$-0.05(0.16) \quad 27.2$

$0.03(0.17) \quad 28.0$

$0.03(0.17)$

30.7

$-0.01(0.17) \quad 28.0$

$0.05(0.18)$

28.4

$0.04(0.18)$

28.0

$0.17(0.17) \quad 31.5 \quad 0.27(0.17)$

32.1

$0.26(0.17)$

28.2

$\$ 50 \mathrm{~K}+$

Education

Less than high school

$\begin{array}{cc}- & 27.8 \\ 0.05(0.10) & 28.7 \\ -0.04(0.09) & 27.0 \\ 0.14(0.12) & 30.6 \\ 0.21(0.13) & 32.0\end{array}$

-
$-0.00(0.11)$
$-0.11(0.09)$
$0.02(0.14)$
$0.08(0.13)$

29.1

$\begin{array}{cc}- & 29.0 \\ -0.00(0.11) & 29.0 \\ -0.11(0.10) & 27.2 \\ 0.02(0.14) & 29.4 \\ 0.09(0.13) & 30.5\end{array}$

Help

Spouse, child, parent

$-$

$-0.27(0.13)^{*}$

$-0.28(0.13)^{*}$

help only

Paid help only

Unpaid help only

Multiple types of help

$-0.07(0.13)$

$-0.07(0.13)$

$-$

$1.59(0.13)^{*}$

$1.59(0.13)^{*}$

Mobility Aids

Cane or crutch

Walker

Manual Wheelchair

Electric Wheelchair or

scooter

Brace

$-0.10(0.09)$

$-0.11(0.13)$

$0.03(0.15)$

$0.70(0.33)^{*}$

$-0.21(0.16)$

N

4905

4905

4905

These models include only respondents who reported intrinsic disability and use of help Models all control for race, age*sex, sex*marital status, functional limitations and whether respondents reported difficulty with 3 or more IADLs $* \mathrm{p}<0.05$ 
Table 12. Use of equipment and personal help among respondents with intrinsic disability, by any ADL and any IADL category, separately for men and women*

\begin{tabular}{lcccc}
\hline & \multicolumn{2}{c}{ Men } & \multicolumn{2}{c}{ Women } \\
\hline & Any ADL & Any IADL & Any ADL & Any IADL \\
Any equipment & 54.6 & - & 56.8 & - \\
Any personal help & 69.3 & 87.5 & 62.0 & 88.9 \\
$\quad$ Spouse/child/parent & 31.0 & 27.4 & 17.7 & 24.6 \\
$\quad$ Paid & 20.5 & 28.1 & 27.7 & 30.7 \\
$\quad$ Other unpaid & 21.2 & 24.2 & 21.3 & 28.7 \\
Either equipment or personal & 91.5 & - & 89.7 & - \\
help & & & & \\
N & 751 & 1729 & & \\
& & & & \\
*Categories are not mutually exclusive & & & \\
\hline
\end{tabular}


Table 13. Logistic regression models for coping for getting around inside and dressing, including covariates for use of equipment and help

\begin{tabular}{cccccccc}
\hline \multicolumn{3}{c}{ Getting Around Inside } & \multicolumn{4}{c}{ Dressing } \\
\hline $\begin{array}{c}\text { Coefficient } \\
(\text { SE })\end{array}$ & $\begin{array}{c}\text { Adjusted } \\
\text { percent }\end{array}$ & $\begin{array}{c}\text { Coefficient } \\
(\text { SE) }\end{array}$ & $\begin{array}{c}\text { Adjusted } \\
\text { percent }\end{array}$ & $\begin{array}{c}\text { Coefficient } \\
\text { (SE) }\end{array}$ & $\begin{array}{c}\text { Adjusted } \\
\text { percent }\end{array}$ & $\begin{array}{c}\text { Coefficient } \\
\text { (SE) }\end{array}$ & $\begin{array}{c}\text { Adjusted } \\
\text { percent }\end{array}$ \\
\hline
\end{tabular}

Income

$\$ 0-\$ 9,999$

$\$ 10 \mathrm{~K}-\$ 19,000$

\begin{tabular}{|c|c|c|}
\hline - & 33.6 & - \\
\hline-0.13 & 31.1 & -0.13 \\
\hline$(0.22)$ & & $(0.22)$ \\
\hline-0.44 & 25.6 & -0.43 \\
\hline$(0.28)$ & & $(0.28)$ \\
\hline-0.15 & 30.7 & -0.15 \\
\hline$(0.31)$ & & $(0.31)$ \\
\hline-0.59 & 23.2 & -0.61 \\
\hline$(0.43)$ & & $(0.43)$ \\
\hline 0.23 & 38.3 & 0.23 \\
\hline$(0.33)$ & & $(0.33)$ \\
\hline
\end{tabular}

33.6

34.6

34.4

\$20K - \$29,999

$\$ 20 \mathrm{~K}-\$ 29,999$

$(0.22)$

31.2

0.32

41.2

-

41.0

$(0.23)$

25.7

0.30

40.7

0.31

(0.27)

30.7

$-0.04$

(0.27)

$\$ 30 \mathrm{~K}-\$ 39,999$

$(0.31)$

$\$ 40 \mathrm{~K}-\$ 49,999$

$(0.43)$

$\$ 50 \mathrm{~K}+$

$$
\text { (0.33) }
$$

(0.30)

22.9

$-0.67$

(0.45)

38.2

0.51

(0.30)

0.02

33.9

(0.30)

22.5

$-0.66$

(0.44)

45.4

0.53

(0.31)

40.9

34.9

22.7

45.6

Education

Less than HS

Some HS

$\begin{array}{ccc}- & 27.3 & - \\ 0.37 & 34.2 & 0.40 \\ (0.23) & & (0.23) \\ 0.18 & 30.6 & 0.19 \\ (0.21) & & (0.22) \\ 0.49 & 36.5 & 0.52 \\ (0.32) & & (0.33) \\ 0.20 & 30.8 & 0.20 \\ (0.34) & & (0.34)\end{array}$

27.1

32.2

42.7

-

0.52

$(0.21)^{*}$

HS graduate

0.18

Some college

0.49

College grad +

$$
\text { (0.34) }
$$

(0.34)

34.5

$(0.21)^{*}$

30.6

0.24

(0.20)

36.9

0.45

$(0.28)$

30.7

0.99

$(0.28)^{*}$

37.0

0.28

(0.20)

41.3

0.46

(0.28)

53.4

1.03

$(0.28)^{*}$

31.9

42.5

37.5

41.2

53.8

Equipment and help

Equipment and help

Equipment only

0.17

(0.27)

0.59

(0.75)

0.34

(0.27)

0.94

$(0.41)^{*}$

$\mathrm{N}$

890

890

924

924

These models include only respondents who reported intrinsic disability and use of either help and/or AT

Models all control for race, age*sex, sex*marital status, functional limitations and whether respondents report difficulty with 3 or more ADLs

$* \mathrm{p}<0.05$ 
Table 14. Logistic regression models for coping for shopping and light housework, including covariates for specific mobility aids

\begin{tabular}{|c|c|c|c|c|c|c|c|c|}
\hline & \multicolumn{4}{|c|}{ Shopping } & \multicolumn{4}{|c|}{ Light Housework } \\
\hline & $\begin{array}{l}\text { Coefficient } \\
\text { (SE) }\end{array}$ & $\begin{array}{l}\text { Adjusted } \\
\text { percent }\end{array}$ & $\begin{array}{c}\text { Coefficient } \\
\text { (SE) }\end{array}$ & $\begin{array}{c}\text { Adjusted } \\
\text { percent }\end{array}$ & $\begin{array}{c}\text { Coefficient } \\
\text { (SE) }\end{array}$ & $\begin{array}{c}\text { Adjusted } \\
\text { percent }\end{array}$ & $\begin{array}{c}\text { Coefficient } \\
(\mathrm{SE})\end{array}$ & $\begin{array}{c}\text { Adjusted } \\
\text { percent }\end{array}$ \\
\hline \multicolumn{9}{|l|}{ Income } \\
\hline$\$ 0-\$ 9,999$ & - & 33.6 & - & 33.6 & - & 25.9 & - & 25.7 \\
\hline$\$ 10 \mathrm{~K}-\$ 19,000$ & $\begin{array}{c}0.06 \\
(0.13)\end{array}$ & 34.8 & $\begin{array}{c}0.06 \\
(0.13)\end{array}$ & 34.9 & $\begin{array}{c}0.23 \\
(0.17)\end{array}$ & 30.4 & $\begin{array}{c}0.24 \\
(0.17)\end{array}$ & 30.4 \\
\hline$\$ 20 \mathrm{~K}-\$ 29,999$ & $\begin{array}{c}0.13 \\
(0.16)\end{array}$ & 36.4 & $\begin{array}{c}0.12 \\
(0.16)\end{array}$ & 36.2 & $\begin{array}{c}0.41 \\
(0.20)^{*}\end{array}$ & 34.3 & $\begin{array}{c}0.43 \\
(0.20)^{*}\end{array}$ & 34.4 \\
\hline$\$ 30 \mathrm{~K}-\$ 39,999$ & $\begin{array}{c}0.31 \\
(0.19)\end{array}$ & 40.3 & $\begin{array}{c}0.30 \\
(0.19)\end{array}$ & 40.1 & $\begin{array}{c}0.26 \\
(0.24)\end{array}$ & 31.0 & $\begin{array}{c}0.27 \\
(0.24)\end{array}$ & 31.0 \\
\hline$\$ 40 \mathrm{~K}-\$ 49,999$ & $\begin{array}{l}-0.16 \\
(0.22)\end{array}$ & 30.3 & $\begin{array}{l}-0.19 \\
(0.22)\end{array}$ & 29.9 & $\begin{array}{c}0.44 \\
(0.27)\end{array}$ & 34.8 & $\begin{array}{c}0.46 \\
(0.27)\end{array}$ & 35.1 \\
\hline$\$ 50 \mathrm{~K}+$ & $\begin{array}{l}-0.07 \\
(0.21)\end{array}$ & 32.1 & $\begin{array}{l}-0.09 \\
(0.21)\end{array}$ & 31.8 & $\begin{array}{c}0.33 \\
(0.25)\end{array}$ & 32.5 & $\begin{array}{c}0.32 \\
(0.25)\end{array}$ & 31.9 \\
\hline \multicolumn{9}{|l|}{ Education } \\
\hline Less than HS & - & 34.7 & - & 34.6 & - & 28.7 & - & 28.7 \\
\hline Some HS & $\begin{array}{c}0.06 \\
(0.15)\end{array}$ & 35.9 & $\begin{array}{c}0.05 \\
(0.16)\end{array}$ & 35.7 & $\begin{array}{c}0.10 \\
(0.17)\end{array}$ & 30.6 & $\begin{array}{c}0.09 \\
(0.17)\end{array}$ & 30.5 \\
\hline HS graduate & $\begin{array}{l}-0.03 \\
(0.13)\end{array}$ & 34.1 & $\begin{array}{l}-0.02 \\
(0.13)\end{array}$ & 34.2 & $\begin{array}{c}0.10 \\
(0.15)\end{array}$ & 30.7 & $\begin{array}{c}0.10 \\
(0.15)\end{array}$ & 30.7 \\
\hline Some college & $\begin{array}{c}0.01 \\
(0.20)\end{array}$ & 34.8 & $\begin{array}{c}0.02 \\
(0.20)\end{array}$ & 34.9 & $\begin{array}{c}0.12 \\
(0.22)\end{array}$ & 31.1 & $\begin{array}{c}0.14 \\
(0.23)\end{array}$ & 31.5 \\
\hline College grad + & $\begin{array}{l}-0.04 \\
(0.22)\end{array}$ & 33.7 & $\begin{array}{l}-0.04 \\
(0.22)\end{array}$ & 33.7 & $\begin{array}{c}0.23 \\
(0.23)\end{array}$ & 33.4 & $\begin{array}{c}0.22 \\
(0.24)\end{array}$ & 33.2 \\
\hline \multicolumn{9}{|l|}{ Mobility Aids } \\
\hline Cane or crutch & & & $\begin{array}{l}-0.18 \\
(0.10)\end{array}$ & & & & $\begin{array}{c}0.06 \\
(0.11)\end{array}$ & \\
\hline Walker & & & $\begin{array}{c}0.04 \\
(0.11)\end{array}$ & & & & $\begin{array}{l}-0.20 \\
(0.14)\end{array}$ & \\
\hline Manual & & & 0.07 & & & & -0.02 & \\
\hline Wheelchair & & & $(0.14)$ & & & & $(0.16)$ & \\
\hline Electric & & & 0.49 & & & & 0.56 & \\
\hline $\begin{array}{l}\text { wheelchair or } \\
\text { scooter }\end{array}$ & & & $(0.34)$ & & & & $(0.39)$ & \\
\hline Brace & & & $\begin{array}{l}-0.26 \\
(0.23)\end{array}$ & & & & $\begin{array}{l}-0.01 \\
(0.25)\end{array}$ & \\
\hline $\mathrm{N}$ & 2187 & & 2187 & & 1534 & & 1534 & \\
\hline $\begin{array}{l}\text { These models in } \\
\text { Models all contr } \\
\text { with } 3 \text { or more } \mathrm{I} \\
{ }^{*} \mathrm{p}<0.05\end{array}$ & $\begin{array}{l}\text { only respon } \\
\text { race, age*s }\end{array}$ & $\begin{array}{l}\text { ents who } \\
\text { sex*ma }\end{array}$ & $\begin{array}{l}\text { orted intrir } \\
\text { I status, fu }\end{array}$ & $\begin{array}{l}\text { disabilit } \\
\text { onal lim }\end{array}$ & $\begin{array}{l}\text { nd use of e } \\
\text { ions and w }\end{array}$ & $\begin{array}{l}\text { help a } \\
\text { er resp }\end{array}$ & $\begin{array}{l}\text { /or AT } \\
\text { dents report }\end{array}$ & difficulty \\
\hline
\end{tabular}




\section{Appendix}

Table A. Logistic Regression Models for Ability to Cope by Sex

\begin{tabular}{|c|c|c|c|c|}
\hline & \multicolumn{2}{|c|}{ Any Disability: Men } & \multicolumn{2}{|c|}{ Any Disability: Women } \\
\hline & Coefficient (SE) & Adjusted percent & Coefficient (SE) & Adjusted percent \\
\hline \multicolumn{5}{|l|}{ Income } \\
\hline$\$ 0-\$ 9,999$ & - & 18.2 & - & 24.6 \\
\hline$\$ 10 \mathrm{~K}-\$ 19,000$ & $0.11(0.20)$ & 19.9 & $-0.09(0.11)$ & 23.0 \\
\hline$\$ 20 \mathrm{~K}-\$ 29,999$ & $0.41(0.22)$ & 24.9 & $-0.08(0.13)$ & 23.2 \\
\hline$\$ 30 \mathrm{~K}-\$ 39,999$ & $0.08(0.28)$ & 19.4 & $-0.14(0.17)$ & 22.2 \\
\hline$\$ 40 \mathrm{~K}-\$ 49,999$ & $0.40(0.30)$ & 24.7 & $-0.01(0.20)$ & 2445 \\
\hline$\$ 50 \mathrm{~K}+$ & $0.63(0.28)^{*}$ & 29.0 & $0.00(0.18)$ & 24.7 \\
\hline \multicolumn{5}{|l|}{ Education } \\
\hline Less than high school & - & 22.2 & - & 20.5 \\
\hline Some HS & $-0.11(0.19)$ & 20.4 & $0.22(0.12)$ & 24.2 \\
\hline HS graduate & $-0.21(0.18)$ & 18.9 & $0.21(0.10)^{*}$ & 24.1 \\
\hline Some college & $0.05(0.23)$ & 23.0 & $0.46(0.15)^{*}$ & 28.6 \\
\hline College grad or higher & $0.31(0.24)$ & 27.8 & $0.34(0.16)^{*}$ & 26.4 \\
\hline \multicolumn{5}{|l|}{ Age } \\
\hline $70-74$ & $0.00(0.16)$ & & $0.23(0.12)^{*}$ & \\
\hline $75-79$ & $0.14(0.18)$ & & $0.13(0.13)$ & \\
\hline $80-84$ & $0.14(0.18)$ & & $0.18(0.13)$ & \\
\hline 85plus & $-0.29(0.19)$ & & $0.13(0.14)$ & \\
\hline \multicolumn{5}{|l|}{ Marital status } \\
\hline Widowed & $0.08(0.15)$ & & $0.04(0.10)$ & \\
\hline Dsepsing & $0.02(0.20)$ & & $-0.21(0.15)$ & \\
\hline \multicolumn{5}{|l|}{ Race } \\
\hline Black/other race & $0.04(0.20)$ & & $0.11(0.13)$ & \\
\hline \multicolumn{5}{|l|}{ Severity of Limitations } \\
\hline 1-2 ADLs & $-0.12(0.15)$ & & $-0.39(0.10)^{*}$ & \\
\hline 3 or more ADLs & $-1.32(0.24)^{*}$ & & $-1.73(0.18)^{*}$ & \\
\hline $\mathrm{N}$ & 1865 & & 4003 & \\
\hline
\end{tabular}

The definition of intrinsic ADL disability includes difficulty alone or without help or equipment; the definition for intrinsic IADL disability includes only difficulty alone or without help.

These models include only respondents who reported intrinsic disability

Reference groups for age, marital status, race and severity of limitations are age 65-59, married respondents, white respondents and respondents reporting only IADL disability respectively.

$* \mathrm{p}<0.05$ 
Table B. Logistic Regression Models for Intrinsic Disability, Income Only

\begin{tabular}{|c|c|c|c|c|c|c|}
\hline \multirow[b]{2}{*}{$\begin{array}{l}\text { Independent } \\
\text { Variable }\end{array}$} & \multicolumn{2}{|c|}{ Any Disability } & \multicolumn{2}{|c|}{ Any ADL } & \multicolumn{2}{|c|}{ Any IADL } \\
\hline & $\begin{array}{l}\text { Coefficient } \\
\text { (SE) }\end{array}$ & $\begin{array}{l}\text { Adjusted } \\
\text { percent }\end{array}$ & $\begin{array}{l}\text { Coefficient } \\
\text { (SE) }\end{array}$ & $\begin{array}{l}\text { Adjusted } \\
\text { percent }\end{array}$ & $\begin{array}{l}\text { Coefficient } \\
\text { (SE) }\end{array}$ & $\begin{array}{c}\text { Adjusted } \\
\text { percent }\end{array}$ \\
\hline \multicolumn{7}{|l|}{ Income } \\
\hline$\$ 0$ - \$9,999 & - & 29.8 & - & 11.1 & - & 27.8 \\
\hline$\$ 10 \mathrm{~K}-\$ 19,000$ & $-0.28(0.05)^{*}$ & 24.6 & $-0.27(0.06)^{*}$ & 8.9 & $-0.26(0.05)^{*}$ & 23.2 \\
\hline$\$ 20 \mathrm{~K}-\$ 29,999$ & $-0.38(0.06)^{*}$ & 23.1 & $-0.23(0.08) *$ & 9.2 & $-0.34(0.06)^{*}$ & 22.0 \\
\hline$\$ 30 \mathrm{~K}-\$ 39,999$ & $-0.44(0.07)^{*}$ & 22.0 & $-0.27(0.10)^{*}$ & 8.8 & $-0.40(0.07)^{*}$ & 21.0 \\
\hline$\$ 40 \mathrm{~K}-\$ 49,999$ & $-0.31(0.08)^{*}$ & 24.1 & $-0.24(0.11)^{*}$ & 9.0 & $-0.28(0.08)^{*}$ & 22.9 \\
\hline$\$ 50 \mathrm{~K}+$ & $-0.59(0.07)^{*}$ & 19.8 & $-0.36(0.11)^{*}$ & 8.2 & $-0.55(0.07)^{*}$ & 18.7 \\
\hline \multicolumn{7}{|l|}{ Education } \\
\hline $\begin{array}{l}\text { Less than high } \\
\text { school }\end{array}$ & - & & - & & - & \\
\hline Some HS & - & & - & & - & \\
\hline HS graduate & - & & - & & - & \\
\hline Some college & - & & - & & - & \\
\hline $\begin{array}{l}\text { College grad or } \\
\text { higher }\end{array}$ & - & & - & & - & \\
\hline $\mathrm{N}$ & 24,476 & & 24,476 & & 24,476 & \\
\hline \multicolumn{7}{|c|}{$\begin{array}{l}\text { The definition of intrinsic ADL disability includes difficulty alone or without help or equipment; the } \\
\text { definition for intrinsic IADL disability includes only difficulty alone or without help. } \\
\text { Individuals missing values for educational attainment }(n=295) \text { and/or marital status }(n=25) \text { were dropped } \\
\text { from regression analyses } \\
* p<0.05\end{array}$} \\
\hline
\end{tabular}


Table C. Logistic Regression Models for Intrinsic Disability, Education Only

\begin{tabular}{|c|c|c|c|c|c|c|}
\hline \multirow[b]{2}{*}{$\begin{array}{l}\text { Independent } \\
\text { Variable }\end{array}$} & \multicolumn{2}{|c|}{ Any Disability } & \multicolumn{2}{|c|}{ Any ADL } & \multicolumn{2}{|c|}{ Any IADL } \\
\hline & $\begin{array}{l}\text { Coefficient } \\
\text { (SE) }\end{array}$ & $\begin{array}{c}\text { Adjusted } \\
\text { percent }\end{array}$ & $\begin{array}{l}\text { Coefficient } \\
\text { (SE) }\end{array}$ & $\begin{array}{c}\text { Adjusted } \\
\text { percent }\end{array}$ & $\begin{array}{l}\text { Coefficient } \\
\text { (SE) }\end{array}$ & $\begin{array}{c}\text { Adjusted } \\
\text { percent }\end{array}$ \\
\hline \multicolumn{7}{|l|}{ Income } \\
\hline$\$ 0-\$ 9,999$ & - & & - & & - & \\
\hline$\$ 10 \mathrm{~K}-\$ 19,000$ & - & & - & & - & \\
\hline$\$ 20 \mathrm{~K}-\$ 29,999$ & - & & - & & - & \\
\hline$\$ 30 \mathrm{~K}-\$ 39,999$ & - & & - & & - & \\
\hline$\$ 40 \mathrm{~K}-\$ 49,999$ & - & & - & & - & \\
\hline$\$ 50 \mathrm{~K}+$ & - & & - & & - & \\
\hline \multicolumn{7}{|l|}{ Education } \\
\hline $\begin{array}{l}\text { Less than high } \\
\text { school }\end{array}$ & - & 28.8 & - & 11.4 & - & 27.0 \\
\hline Some HS & $-0.10(0.05)^{*}$ & 26.9 & $-0.08(0.07)$ & 10.7 & $-0.09(0.05)$ & 25.5 \\
\hline HS graduate & $-0.29(0.04) *$ & 23.5 & $-0.31(0.06)^{*}$ & 8.7 & $-0.29(0.05)^{*}$ & 22.1 \\
\hline Some college & $-0.48(0.06)^{*}$ & 20.6 & $-0.47(0.09)^{*}$ & 7.6 & $-0.46(0.06)^{*}$ & 19.5 \\
\hline $\begin{array}{l}\text { College grad or } \\
\text { higher }\end{array}$ & $-0.49(0.06)^{*}$ & 20.5 & $-0.64(0.09) *$ & 6.6 & $-0.44(0.07)^{*}$ & 19.8 \\
\hline $\mathrm{N}$ & 24,476 & & 24,476 & & 24,476 & \\
\hline \multicolumn{7}{|c|}{$\begin{array}{l}\text { The definition of intrinsic ADL disability includes difficulty alone or without help or equipment; the } \\
\text { definition for intrinsic IADL disability includes only difficulty alone or without help. } \\
\text { Individuals missing values for educational attainment }(n=295) \text { and/or marital status }(n=25) \text { were dropped } \\
\text { from regression analyses } \\
* p<0.05\end{array}$} \\
\hline
\end{tabular}


Table D. Logistic Regression Models for Residual Disability, Income Only

\begin{tabular}{|c|c|c|c|c|c|c|}
\hline \multirow[b]{2}{*}{$\begin{array}{l}\text { Independent } \\
\text { Variable }\end{array}$} & \multicolumn{2}{|c|}{ Any Disability } & \multicolumn{2}{|c|}{ ADL Only } & \multicolumn{2}{|c|}{ IADL Only } \\
\hline & $\begin{array}{c}\text { Coefficient } \\
(\mathrm{SE})\end{array}$ & $\begin{array}{c}\text { Adjusted } \\
\text { percent }\end{array}$ & $\begin{array}{l}\text { Coefficient } \\
\text { (SE) }\end{array}$ & $\begin{array}{c}\text { Adjusted } \\
\text { percent }\end{array}$ & $\begin{array}{l}\text { Coefficient } \\
(\mathrm{SE})\end{array}$ & $\begin{array}{c}\text { Adjusted } \\
\text { percent }\end{array}$ \\
\hline \multicolumn{7}{|l|}{ Income } \\
\hline$\$ 0-\$ 9,999$ & - & 22.9 & - & 7.8 & - & 20.9 \\
\hline$\$ 10 \mathrm{~K}-\$ 19,000$ & $-0.24(0.05)^{*}$ & 19.1 & $-0.28(0.07)^{*}$ & 6.1 & $-0.22(0.05)^{*}$ & 17.7 \\
\hline$\$ 20 \mathrm{~K}-\$ 29,999$ & $-0.36(0.06)^{*}$ & 17.5 & $-0.29(0.09)^{*}$ & 6.0 & $-0.34(0.07)^{*}$ & 16.1 \\
\hline$\$ 30 \mathrm{~K}-\$ 39,999$ & $-0.38(0.08)^{*}$ & 17.2 & $-0.27(0.11)^{*}$ & 6.1 & $-0.36(0.08)^{*}$ & 15.8 \\
\hline$\$ 40 \mathrm{~K}-\$ 49,999$ & $-0.32(0.09)^{*}$ & 18.0 & $-0.19(0.13)$ & 6.6 & $-0.30(0.10)^{*}$ & 16.6 \\
\hline$\$ 50 \mathrm{~K}+$ & $-0.60(0.08)^{*}$ & 14.4 & $-0.52(0.15)^{*}$ & 4.9 & $-0.58(0.09)^{*}$ & 13.2 \\
\hline \multicolumn{7}{|l|}{ Education } \\
\hline $\begin{array}{l}\text { Less than high } \\
\text { school }\end{array}$ & - & & - & & - & \\
\hline Some HS & - & & - & & - & \\
\hline HS graduate & - & & - & & - & \\
\hline Some college & - & & - & & - & \\
\hline $\begin{array}{l}\text { College grad or } \\
\text { higher }\end{array}$ & - & & - & & - & \\
\hline $\mathrm{N}$ & 24,476 & & 24,476 & & 24,476 & \\
\hline \multicolumn{7}{|c|}{$\begin{array}{l}\text { The definition of intrinsic ADL disability includes difficulty alone or without help or equipment; the } \\
\text { definition for intrinsic IADL disability includes only difficulty alone or without help. } \\
\text { Individuals missing values for educational attainment }(n=295) \text { and/or marital status }(n=25) \text { were dropped } \\
\text { from regression analyses } \\
* p<0.05\end{array}$} \\
\hline
\end{tabular}


Table E. Logistic Regression Models for Residual Disability, Education Only

\begin{tabular}{|c|c|c|c|c|c|c|}
\hline \multirow[b]{2}{*}{$\begin{array}{l}\text { Independent } \\
\text { Variable }\end{array}$} & \multicolumn{2}{|c|}{ Any Disability } & \multicolumn{2}{|c|}{ Any ADL } & \multicolumn{2}{|c|}{ Any IADL } \\
\hline & $\begin{array}{l}\text { Coefficient } \\
\text { (SE) }\end{array}$ & $\begin{array}{l}\text { Adjusted } \\
\text { percent }\end{array}$ & $\begin{array}{l}\text { Coefficient } \\
\text { (SE) }\end{array}$ & $\begin{array}{l}\text { Adjusted } \\
\text { percent }\end{array}$ & $\begin{array}{l}\text { Coefficient } \\
\text { (SE) }\end{array}$ & $\begin{array}{c}\text { Adjusted } \\
\text { percent }\end{array}$ \\
\hline \multicolumn{7}{|l|}{ Income } \\
\hline$\$ 0$ - \$9,999 & - & & - & & - & \\
\hline$\$ 10 \mathrm{~K}-\$ 19,000$ & - & & - & & - & \\
\hline$\$ 20 \mathrm{~K}-\$ 29,999$ & - & & - & & - & \\
\hline$\$ 30 \mathrm{~K}-\$ 39,999$ & - & & - & & - & \\
\hline$\$ 40 \mathrm{~K}-\$ 49,999$ & - & & - & & - & \\
\hline$\$ 50 \mathrm{~K}+$ & - & & - & & - & \\
\hline \multicolumn{7}{|l|}{ Education } \\
\hline $\begin{array}{l}\text { Less than high } \\
\text { school }\end{array}$ & - & 22.8 & - & 8.4 & - & 20.6 \\
\hline Some HS & $-0.13(0.05)^{*}$ & 20.7 & $-0.19(0.08)^{*}$ & 7.1 & $-0.11(0.05)^{*}$ & 19.0 \\
\hline HS graduate & $-0.30(0.05)^{*}$ & 18.2 & $-0.43(0.08)^{*}$ & 5.7 & $-0.27(0.05)^{*}$ & 16.8 \\
\hline Some college & $-0.54(0.06)^{*}$ & 15.0 & $-0.66(0.11)^{*}$ & 4.6 & $-0.50(0.06)^{*}$ & 13.9 \\
\hline $\begin{array}{l}\text { College grad or } \\
\text { higher }\end{array}$ & $-0.58(0.07)^{*}$ & 14.6 & $-0.70(0.10)^{*}$ & 4.5 & $-0.52(0.07)^{*}$ & 13.7 \\
\hline $\mathrm{N}$ & 24,476 & & 24,476 & & 24,476 & \\
\hline \multicolumn{7}{|c|}{$\begin{array}{l}\text { The definition of intrinsic ADL disability includes difficulty alone or without help or equipment; the } \\
\text { definition for intrinsic IADL disability includes only difficulty alone or without help. } \\
\text { Individuals missing values for educational attainment }(n=295) \text { and/or marital status }(n=25) \text { were dropped } \\
\text { from regression analyses } \\
* \text { p }<0.05\end{array}$} \\
\hline
\end{tabular}


Table F. Logistic Regression Models for Coping, Income Only

\begin{tabular}{|c|c|c|c|c|c|c|}
\hline \multirow[b]{2}{*}{$\begin{array}{l}\text { Independent } \\
\text { Variable }\end{array}$} & \multicolumn{2}{|c|}{ Any Disability } & \multicolumn{2}{|c|}{ Any ADL } & \multicolumn{2}{|c|}{ Any IADL } \\
\hline & $\begin{array}{l}\text { Coefficient } \\
\text { (SE) }\end{array}$ & $\begin{array}{c}\text { Adjusted } \\
\text { percent }\end{array}$ & $\begin{array}{l}\text { Coefficient } \\
\text { (SE) }\end{array}$ & $\begin{array}{c}\text { Adjusted } \\
\text { percent }\end{array}$ & $\begin{array}{l}\text { Coefficient } \\
\text { (SE) }\end{array}$ & $\begin{array}{c}\text { Adjusted } \\
\text { percent }\end{array}$ \\
\hline \multicolumn{7}{|l|}{ Income } \\
\hline$\$ 0-\$ 9,999$ & - & 22.4 & - & 29.3 & - & 24.6 \\
\hline$\$ 10 \mathrm{~K}-\$ 19,000$ & $-0.02(0.09)$ & 22.1 & $0.15(0.14)$ & 32.2 & $-0.04(0.10)$ & 23.9 \\
\hline$\$ 20 \mathrm{~K}-\$ 29,999$ & $0.11(0.11)$ & 24.3 & $0.25(0.16)$ & 34.0 & $0.12(0.11)$ & 26.9 \\
\hline$\$ 30 \mathrm{~K}-\$ 39,999$ & $-0.02(0.15)$ & 22.1 & $0.11(0.19)$ & 31.3 & $-0.00(0.15)$ & 24.6 \\
\hline$\$ 40 \mathrm{~K}-\$ 49,999$ & $0.16(0.17)$ & 25.2 & $0.11(0.27)$ & 31.4 & $0.10(0.16)$ & 26.4 \\
\hline$\$ 50 \mathrm{~K}+$ & $0.28(0.15)$ & 27.4 & $0.52(0.24)^{*}$ & 39.5 & $0.24(0.15)$ & 29.2 \\
\hline \multicolumn{7}{|l|}{ Education } \\
\hline $\begin{array}{l}\text { Less than high } \\
\text { school }\end{array}$ & - & & - & & - & \\
\hline Some HS & - & & - & & - & \\
\hline HS graduate & - & & - & & - & \\
\hline Some college & - & & - & & - & \\
\hline $\begin{array}{l}\text { College grad or } \\
\text { higher }\end{array}$ & - & & - & & - & \\
\hline $\mathrm{N}$ & 5868 & & 2266 & & 5557 & \\
\hline \multicolumn{7}{|c|}{$\begin{array}{l}\text { The definition of intrinsic ADL disability includes difficulty alone or without help or equipment; the } \\
\text { definition for intrinsic IADL disability includes only difficulty alone or without help. } \\
\text { Individuals missing values for educational attainment }(n=295) \text { and/or marital status }(n=25) \text { were dropped } \\
\text { from regression analyses } \\
* p<0.05\end{array}$} \\
\hline
\end{tabular}


Table G. Logistic Regression Models for Coping, Education Only

\begin{tabular}{|c|c|c|c|c|c|c|}
\hline \multirow[b]{2}{*}{$\begin{array}{l}\text { Independent } \\
\text { Variable }\end{array}$} & \multicolumn{2}{|c|}{ Any Disability } & \multicolumn{2}{|c|}{ Any ADL } & \multicolumn{2}{|c|}{ Any IADL } \\
\hline & $\begin{array}{l}\text { Coefficient } \\
\text { (SE) }\end{array}$ & $\begin{array}{c}\text { Adjusted } \\
\text { percent }\end{array}$ & $\begin{array}{l}\text { Coefficient } \\
\text { (SE) }\end{array}$ & $\begin{array}{c}\text { Adjusted } \\
\text { percent }\end{array}$ & $\begin{array}{l}\text { Coefficient } \\
\text { (SE) }\end{array}$ & $\begin{array}{c}\text { Adjusted } \\
\text { percent }\end{array}$ \\
\hline \multicolumn{7}{|l|}{ Income } \\
\hline$\$ 0-\$ 9,999$ & - & & - & & - & \\
\hline$\$ 10 \mathrm{~K}-\$ 19,000$ & - & & - & & - & \\
\hline$\$ 20 K-\$ 29,999$ & - & & - & & - & \\
\hline$\$ 30 \mathrm{~K}-\$ 39,999$ & - & & - & & - & \\
\hline$\$ 40 \mathrm{~K}-\$ 49,999$ & - & & - & & - & \\
\hline$\$ 50 \mathrm{~K}+$ & - & & - & & - & \\
\hline \multicolumn{7}{|l|}{ Education } \\
\hline $\begin{array}{l}\text { Less than high } \\
\text { school }\end{array}$ & - & 20.7 & - & 26.9 & - & 24.2 \\
\hline Some HS & $0.13(0.10)$ & 22.9 & $0.33(0.14)^{*}$ & 32.9 & $0.06(0.09)$ & 25.4 \\
\hline HS graduate & $0.11(0.08)$ & 22.6 & $0.47(0.13)^{*}$ & 35.7 & $-0.04(0.08)$ & 23.5 \\
\hline Some college & $0.36(0.12)^{*}$ & 27.0 & $0.58(0.20)^{*}$ & 37.9 & $0.21(0.11)$ & 28.3 \\
\hline $\begin{array}{l}\text { College grad or } \\
\text { higher }\end{array}$ & $0.41(0.11)^{*}$ & 28.1 & $0.27(0.20)$ & 31.7 & $0.29(0.11)^{*}$ & 29.9 \\
\hline $\mathrm{N}$ & 5868 & & 2266 & & 5557 & \\
\hline \multicolumn{7}{|c|}{$\begin{array}{l}\text { The definition of intrinsic ADL disability includes difficulty alone or without help or equipment; the } \\
\text { definition for intrinsic IADL disability includes only difficulty alone or without help. } \\
\text { Individuals missing values for educational attainment }(n=295) \text { and/or marital status }(n=25) \text { were dropped } \\
\text { from regression analyses } \\
* \mathrm{p}<0.05\end{array}$} \\
\hline
\end{tabular}


Table H. Logistic regression models for ADL coping among males only, including covariates for use of equipment and help

\begin{tabular}{|c|c|c|c|}
\hline \multicolumn{4}{|c|}{ ADL Only: Men } \\
\hline $\begin{array}{l}\text { Coefficient } \\
\text { (SE) }\end{array}$ & Adjusted percent & Coefficient (SE) & Adjusted percent \\
\hline
\end{tabular}

Income

$\$ 0-\$ 9,999$

$-0.13(0.29)$

33.4

33.4

$\$ 10 \mathrm{~K}-\$ 19,000$

$0.14(0.35)$

31.2

$\$ 20 \mathrm{~K}-\$ 29,999$

$0.03(0.44)$

35.9

31.9

$\$ 30 \mathrm{~K}-\$ 39,999$

$0.70(0.45)$

33.9

46.3

35.8

$\$ 40 \mathrm{~K}-\$ 49,999$

$0.24(0.45)$

37.6

34.8

44.1

$\$ 50 \mathrm{~K}+$

Education

Less than high school

$\begin{array}{cc}- & 30.3 \\ 0.40(0.25) & 37.3 \\ 0.24(0.23) & 34.4 \\ 0.55(0.32) & 40.1 \\ 0.19(0.39) & 33.6\end{array}$

$-0.09(0.30)$

$0.14(0.36)$

$0.08(0.44)$

$0.61(0.48)$

35.8

Some HS

HS graduate

Some college

$0.19(0.39)$

$0.14(0.44)$

29.3

36.0

35.7

40.6

College grad or higher

33.6

35.4

Equipment and help

AT only

Spouse, child, parent

help only

Paid help only

Unpaid help only

Multiple types of help

AT and any help
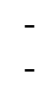

$-$

-

$-$

$-$
$-0.00(0.39)$

$0.19(0.41)$

$-0.43(0.54)$

$1.25(0.48)^{*}$

$-0.33(0.40)$

689

These models include only respondents who reported intrinsic disability and use of either help and/or AT

Models all control for race, age*sex, sex*marital status, functional limitations, and whether respondents report difficulty with 3 or more ADLs

$* \mathrm{p}<0.05$ 
Table I. Logistic regression Models for ADL coping among females only, including covariates for use of equipment and help

ADL Only: Women

Coefficient (SE) $\quad$ Adjusted percent $\quad$ Coefficient (SE) $\quad$ Adjusted percent

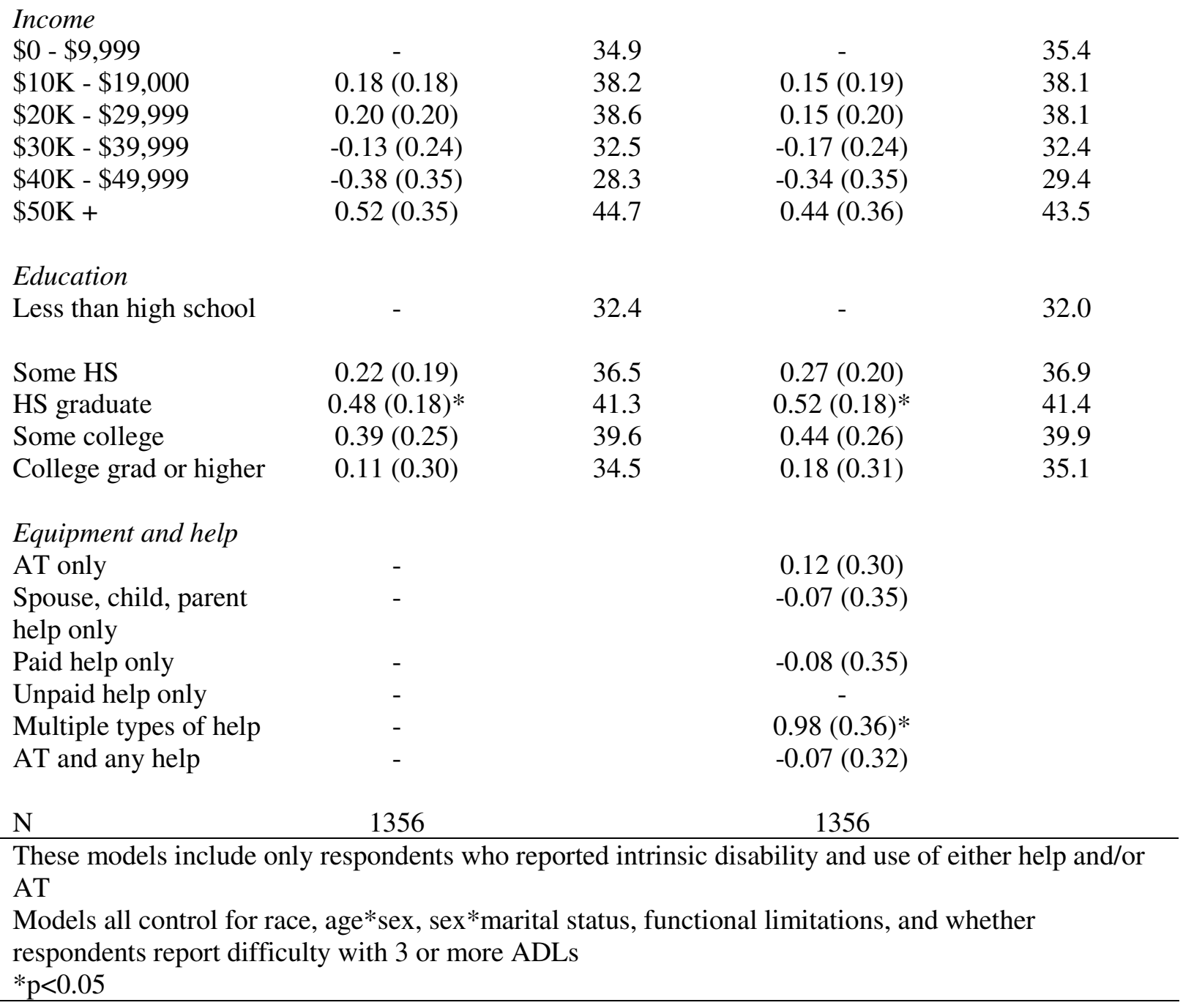


Table J. Logistic regression models for IADL coping for males only, including covariates for use of equipment and help

\begin{tabular}{llll}
\multicolumn{4}{c}{ IADL Only: Men } \\
\hline Coefficient (SE) & Adjusted percent & Coefficient (SE) & Adjusted percent \\
\hline
\end{tabular}

Income

$\$ 0-\$ 9,999$

$\$ 10 \mathrm{~K}-\$ 19,000$

$\$ 20 \mathrm{~K}-\$ 29,999$

$\$ 30 \mathrm{~K}-\$ 39,999$

$\$ 40 \mathrm{~K}-\$ 49,999$

$\$ 50 \mathrm{~K}+$

-

$0.27(0.20)$

$0.62(0.23) *$

$0.32(0.30)$

$0.30(0.34)$

$0.89(0.27)^{*}$

Education

Less than high school

Some HS

HS graduate

Some college

College grad or higher

$\begin{array}{cc}- & 27.2 \\ -0.15(0.21) & 24.5 \\ -0.25(0.19) & 22.8 \\ 0.11(0.21) & 29.2 \\ 0.32(0.25) & 33.6\end{array}$

27.2

24.5

22.8

29.2

33.6
19.5

25.5

31.6

26.9

25.9

37.7

Help

Spouse, child, parent

help only

Paid help only

Unpaid help only

Multiple types of help

$\begin{array}{lc}- & -0.45(0.25) \\ - & -0.29(0.22) \\ - & 1.50(0.21)^{*}\end{array}$

1510

1510

These models include only respondents who reported intrinsic disability and use of either help and/or AT

Models all control for race, age*sex, sex*marital status, functional limitations, and whether respondents report difficulty with 3 or more ADLs

$* \mathrm{p}<0.05$ 
Table K. Logistic regression models for IADL coping for females only, including covariates for use of equipment and help ${ }^{\# \dagger}$

IADL Only: Women

$\begin{array}{llll}\text { Coefficient (SE) } & \text { Adjusted percent } & \text { Coefficient (SE) } & \text { Adjusted percent }\end{array}$

Income

$\$ 0-\$ 9,999$

$\$ 10 \mathrm{~K}-\$ 19,000$

$\$ 20 \mathrm{~K}-\$ 29,999$

$\$ 30 \mathrm{~K}-\$ 39,999$

$\$ 40 \mathrm{~K}-\$ 49,999$

$\$ 50 \mathrm{~K}+$

$-0.14(0.12)$

30.5

29.8

$-0.01(0.15)$

27.9

28.8

$-0.13(0.18)$

30.2

$-0.06(0.12)$

30.1

$-0.04(0.19)$

28.0

28.6

$-0.07(0.19)$

29.7

$0.02(0.16)$

$-0.07(0.19)$

29.8

29.2

$-0.00(0.20)$

29.6

Education

Less than high school

$0.10(0.11)$

$0.00(0.10)$

$0.14(0.15)$

HS graduate

Some college

College grad or higher
28.6

30.4

28.6

31.3

29.5

$-0.01(0.20)$

29.8

$0.05(0.13) \quad 30.7$

$-0.06(0.11) \quad 28.8$

$-0.05(0.16) \quad 28.9$

$-0.10(0.17) \quad 28.1$

Help

Spouse, child, parent

help only

Paid help only

Unpaid help only

Multiple types of help

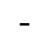

$-$

$-$
$-0.20(0.15)$

$-0.02(0.15)$

$1.66(0.14)^{*}$

3395

These models include only respondents who reported intrinsic disability and use of either help and/or AT

Models all control for race, age*sex, sex*marital status, functional limitations, and whether respondents report difficulty with 3 or more ADLs

$* \mathrm{p}<0.05$ 